\title{
THE HIGH COST OF EDUCATION FEDERALISM
}

\author{
Kimberly Jenkins Robinson*
}

Education federalism in the United States traditionally embraces state and local authority over education and a restricted federal role. 1 Even as the No Child Left Behind Act of 2001 ("NCLB") 2 expanded and transformed the federal role in education, the tradition of state and local control over education influenced key provisions within the statute. ${ }^{3}$ Some praise the nation's longstanding approach to education federalism-which this Article defines as an emphasis on state and local control over education and a limited federal role-for its ability to foster local control of education, encourage experimentation, and promote a robust competition for excellence in education. ${ }^{4}$ This approach to education

* Professor, University of Richmond School of Law. I am thankful for the insightful comments of Jim Gibson, William Koski, Corinna Lain, Martha Minow, Wendy Perdue, James Ryan, and Kevin Walsh. I am grateful for the research assistance of Erin Weaver, Danielle Wingfield, and Melissa Wright.

1 Carl F. Kaestle, Federal Education Policy and the Changing National Polity for Education, 1957-2007, in To EdUCATE A NATION: FEDERAL AND National Strategies of School Reform 17 (Carl F. Kaestle \& Alyssa E. Lodewick eds., 2007).

2. No Child Left Behind Act of 2001, Pub. L. No. 107-110, 115 Stat. 1425 (codified as amended in scattered sections of 20 U.S.C.).

3. See generally Paul Manna, Collision Course: Federal Education Policy MeETs STATE and Local REalities (2011) [hereinafter ManNa, Collision Course]; Paul ManNa, School's In: Federalism and the National Education Agenda (2006) [hereinafter Manna, School's In]; Patrick J. McGuinn, No Child Left Behind and the Transformation of Federal EDUCATION POLICY, 1965-2005 (2006).

4. See, e.g., San Antonio Indep. Sch. Dist. v. Rodriguez, 411 U.S. 1, 49-50 (1973) ("[L]ocal control means ... the freedom to devote more money to the education of one's children. Equally important, however, is the opportunity it offers for participation in the decisionmaking [sic] process that determines how those local tax dollars will be spent.... Pluralism also affords some opportunity for experimentation, innovation, and a healthy competition for educational excellence." (citation omitted)); Wendy Parker, Connecting the Dots: Grutter, School Desegregation, and Federalism, 45 WM. \& MARY L. REV. 1691, 1755 (2004) ("When the choice is between federal court oversight and local or state authority over public schools, then the latter is clearly more consistent with promoting public participation in democracy, preventing tyranny, and encouraging experimentation."); Michael Rebell, Fiscal Equity in Education: Deconstructing the Reigning Myths and Facing Reality, 21 N.Y.U. REV. L. \& SOC. CHANGE 691, 708 (1995) ("[L]ocal control of education remains a worthy 
federalism also is praised for how it enables local communities to respond to local needs and promotes accountability. ${ }^{5}$ The current structure of education federalism resembles the relationship between the national and state governments, and like that relationship, it seeks to capitalize on an array of viewpoints and methods regarding the most effective approaches to education. ${ }^{6}$

Although the nation's current approach to education federalism undoubtedly generates some benefits, it also tolerates substantial inequitable disparities in educational opportunity both within and between states. 7 The reality of local control of education for many communities means the ability to control inadequate resources that provide many students substandard educational opportunities. ${ }^{8}$ The

ideal. Local control encourages diversity, innovation, and experimentation in education.").

5. See Rodriguez, 411 U.S. at 50-51 (noting that through local control of education, "[e]ach locality is free to tailor local programs to local needs"); Richard Briffault, The Role of Local Control in School Finance Reform, 24 CoNN. L. REV. 773, 774, 809 (1992) (noting that some of the benefits of local control are the ability of communities to respond effectively to local needs and to increase accountability); Parker, supra note 4 (arguing that state and local control of education promotes the participation of citizens in democratic government); Rebell, supra note 4 ("Moreover, it [local control] promotes efficiency and direct accountability to those most affected by schooling practices-the parents and citizens who live in that particular community. Perhaps most significantly, local control invites a high level of direct citizen involvement at the grass-roots level. Despite its many shortcomings, the local school district remains the most broad-based and effective vehicle for meaningful participatory democracy in American society.").

6. See Rodriguez, 411 U.S. at 50; Parker, supra note 4, at 1749-50 ("As smaller entities of government, states and localities can experiment with different approaches to maximize the opportunities for success. Lastly, and closely related to the value of promoting states as laboratories for experimentation, is the value of creating communities of shared interests. Allowing experimentation at the state and local level will also allow cultural and local diversity that can benefit any number of viewpoints.").

7. See Michael A. Rebell \& Jessica R. WolfF, Moving Every Child AhEAD: From NCLB Hype to Meaningful EduCATIONAL OpPortunity 39 (2008) ("[P]oor and minority students, whose readiness for learning is severely affected by conditions of poverty, are nevertheless more likely than their more affluent White peers to attend lower-quality schools-however school quality is measured-and to lack adequate educational resources to meet their learning needs."); JAMES E. RYAN, FTve Miles Away, A World Apart: ONe City, Two SCHOOLS, AND THE STORY OF EDUCATIONAL OPPORTUNITY IN MODERN AMERICA 178-79 (2010); Goodwin Liu, Education, Equality, and National Citizenship, 116 YALE L.J. 330, 332 (2006).

8. See Rodriguez, 411 U.S. at 64-65 (White, J., dissenting) ("The difficulty with the Texas system, however, is that it provides a meaningful option to Alamo Heights and like school districts but almost none to Edgewood and those other districts with a low per-pupil real estate tax base. In these latter districts, no matter how desirous parents are of supporting their schools with greater revenues, it is impossible to do so through the use of the real estate property tax. In these districts, the Texas system utterly fails to extend a realistic choice to parents because the property tax, which is the only revenue- 
opportunity divide in American education continues to relegate far too many poor and minority schoolchildren to substandard educational opportunities. ${ }^{9}$ These communities are left behind in the competition for educational excellence. ${ }^{10}$ In addition, highpoverty schools, particularly those within urban school districts, regularly yield the worst academic outcomes. ${ }^{11}$

raising mechanism extended to school districts, is practically and legally unavailable."); REBELL \& WOLFF, supra note 7, at 163 ("Most of the schools that serve low-income and minority students do not have the material or human resources to provide a meaningful educational opportunity to their students, and many schools do not have the capacity to implement school improvement or corrective action plans, no matter how well conceived."); Thomas Kleven, Federalizing Public Education, 55 VILL. L. REv. 369, 393 (2010) ("State and local financing produces substantial inequalities in per pupil educational expenditures. Because local governments' tax bases differ widely within states, so does their ability to raise money to fund education. As a result, the richer school districts in which well-off children tend to live generally spend more money on education and provide a higher quality education than the poorer districts where the less well-off live.").

9. See THE EQUTTY \& EXCELlENCE COMM'N, For EACH AND EVERY CHILD: A STRATEGY FOR EDUCATION EQUITY AND EXCELLENCE 14 (2013) ("Ten million students in America's poorest communities-and millions more African American, Latino, Asian American, Pacific Islander, American Indian and Alaska Native students who are not poor-are having their lives unjustly and irredeemably blighted by a system that consigns them to the lowest-performing teachers, the most run-down facilities, and academic expectations and opportunities considerably lower than what we expect of other students."); REBELL \& WOLFF, supra note 7, at 13 ("Glaring gaps in educational achievement and in educational opportunity persist for the children of our nation's poor, of our immigrants, and of our families of color."); RYAN, supra note 7, at 1.

10. See Rodriguez, 411 U.S. at 127-28 (Marshall, J., dissenting) ("If Texas had a system truly dedicated to local fiscal control, one would expect the quality of the educational opportunity provided in each district to vary with the decision of the voters in that district as to the level of sacrifice they wish to make for public education. In fact, the Texas scheme produces precisely the opposite result. Local school districts cannot choose to have the best education in the State by imposing the highest tax rate. Instead, the quality of the educational opportunity offered by any particular district is largely determined by the amount of taxable property located in the district-a factor over which local voters can exercise no control."); REBELL \& WOLFF, supra note 7, at 13-14 ("In large part, the persistent gap between the American ideal of equality in education and the reality of starkly inadequate schooling for low-income and minority children stems from the irony that although America's dedication to educational equity has surpassed that of any other nation, its commitment to equality in related areas of social welfare has lagged far behind that of other industrialized countries....”); Derek Black, Unlocking the Power of State Constitutions with Equal Protection: The First Step Toward Education as a Federally Protected Right, 51 WM. \& MARY L. REV. 1343, 1354 (2010) (“[S]tates consistently spend less on the education of students who attend predominantly poor and/or minority school districts. Based on the state and national averages, we spend $\$ 908$ less per pupil on students in minority schools than we do on students in predominantly white schools.").

11. RYAN, supra note 7 , at 277. 
These disparities in educational opportunity hinder schools from fulfilling some of their essential national and institutional goals. Schools serve indispensable public functions within a democratic society: they prepare students to engage in the nation's political system in an intelligent and effective manner and transmit the fundamental societal values that a democratic government requires. ${ }^{12}$ The nation also relies on its public schools as the principal institutional guarantor of equal opportunity within American society by serving as a mechanism to ensure that children are not hindered in attaining their dreams by their life circumstances. ${ }^{13}$ Americans depend on schools to address the societal challenges created by social and economic inequality rather than creating the extensive social welfare networks that many industrialized countries have implemented. ${ }^{14}$ The disparities in educational opportunity that relegate many poor and minority students to substandard schooling have hindered the ability of schools to serve these functions. Indeed, rather than solve these challenges, low graduation rates and substandard schools cost the United States billions of dollars each year in lost tax and income revenues, higher health care costs, food stamps, and welfare and housing assistance, to name a few of the costs. ${ }^{15}$

This Article will show the consistent ways that the current understanding of education federalism within the United States has hindered three of the major reform efforts to promote a more equitable distribution of educational opportunity: school desegregation, school finance litigation, and, most recently, NCLB. In exploring how education federalism has undermined these efforts, this Article adds to the understanding of other scholars who have critiqued these reforms ${ }^{16}$ and examined why the nation has

12. Plyler v. Doe, 457 U.S. 202, 221 (1982); Brown v. Bd. of Educ. (Brown I), 347 U.S. 483,493 (1954).

13. Greg J. Duncan \& Richard J. Murnane, Introduction: The American Dream, Then and Now, in WHITHER OPPORTUNITY?: RISING INEQUALITY, Schools, AND ChIldRen's Life Chances 3, 7 (Greg J. Duncan \& Richard J. Murnane eds., 2011).

14. REBELL \& WOLFF, supra note 7, at 26.

15. See Kimberly Jenkins Robinson, The Past, Present, and Future of Equal Educational Opportunity: A Call for a New Theory of Education Federalism, 79 U. CHI. L. REV. 427, 429 (2012) (reviewing RYAN, supra note 7) (summarizing research on the costs of substandard education).

16. For critiques of school desegregation, see, for example, Goodwin Liu, Brown, Bollinger, and Beyond, 47 How. L.J. 705, 718-36 (2004) (critiquing the Court's desegregation decisions for their impatience in achieving results and their indifference to persistent inequality); Wendy Parker, The Future of School Desegregation, 94 NW. U. L. REv. 1157, 1162-78 (2000) (noting that several of the Court's desegregation decisions significantly lessened the burden of proving the absence of vestiges of discrimination but that these decisions still could be interpreted to require a demanding judicial inquiry of school desegregation); Kimberly Jenkins Robinson, Resurrecting the Promise of Brown: Understanding 
failed to guarantee equal educational opportunity. ${ }^{17}$ For example, scholars have argued that the failure to undertake earnest efforts to achieve equal educational opportunity is caused by a variety of factors, including the lack of political will to accomplish this goal,

and Remedying How the Supreme Court Reconstitutionalized Segregated Schools, 88 N.C. L. REV. 787, 811-37 (2010) (analyzing how some of the Court's leading desegregation decisions sanctioned a return to segregated schools). For critiques of Rodriguez and school finance litigation, see, for example, ERWIN Chemerinsky, The Conservative Assault on the Constitution 35-36 (2010) ("The Court held that there is no constitutional right to education and thus that differentials in spending between wealthy and poor school districts within a metropolitan area are constitutionally permissible. If I were to list the most important, and the worst, Supreme Court decisions during my lifetime, Rodriguez would be high on this list."); John Dinan, School Finance Litigation: The Third Wave Recedes, in From Schoolhouse to Courthouse: The Judiciary's Role in AMERICAN EdUCATION 96, 96 (Joshua M. Dunn \& Martin R. West eds., 2009) [hereinafter FrOM SchoolHouse to COURTHOUSE] (addressing how school finance litigation experienced sustained success for almost two decades but now shows signs of faltering); Danielle Holley-Walker, A New Era for Desegregation, 28 GA. ST. U. L. REv. 423, 456-57 (2012) (noting the tendency of school finance cases to ensure only a minimally adequate education); Christopher Roellke et al., School Finance Litigation: The Promises and Limitations of the Third Wave, 79 PEABODY J. EDUC. 104, 105 (2004) ("Despite intensified school finance litigation and legislation over the past several decades, school systems in the United States continue their struggle to operate equitably and adequately. The evidence is clear that these goals of equity and adequacy have been particularly elusive for schools attended primarily by lowincome and minority children."). For critiques of NCLB, see, for example, Regina Ramsey James, How to Mend a Broken Act: Recapturing Those Left Behind by No Child Left Behind, 45 GoNz. L. REV. 683, 691 (2010) ("This Act was passed in a well-intentioned, albeit misguided, effort to curtail educational inequality. However, the NCLB Act, with all its focus on high-stakes tests as indicators of academic success, exacerbates the problem by unduly causing administrators, principals, teachers and most importantly students to stress practicing skills and drills of abstract, often irrelevant-particularly from the students' vantage point-facts likely to be tested, replacing in depth learning with rote memorization."); James E. Ryan, The Perverse Incentives of the No Child Left Behind Act, 79 N.Y.U. L. REV. 932, 934 (2004) (contending that NCLB creates incentives for states to lower academic standards, increase school segregation, push out low-performing students, and discourage good teachers from taking the more challenging jobs).

17. See, e.g., REBELL \& WOLFF, supra note 7, at 13-14 (noting that lowincome and minority communities are not provided equal or adequate educational opportunity and that these communities also have not been able to overcome such obstacles as poor health, inadequate nutrition and housing, racism, and an unstable economy); RYAN, supra note 7, at 1 (arguing that education policy has failed to ensure equal educational opportunity because it has consistently sought to spare suburban schools from efforts to improve urban schools); Black, supra note 10 (arguing that states provide inferior educational funding to predominantly poor and minority school districts); Erwin Chemerinsky, Lost Opportunity: The Burger Court and the Failure to Achieve Equal Educational Opportunity, 45 MERCER L. REV. 999, 1012 (1994) (arguing that Nixon appointees to the Supreme Court voted to uphold court decisions that blocked legal avenues to achieve equal educational opportunity). 
the domination of suburban influences over education politics, and the failure of the United States to create a social welfare system that addresses the social and economic barriers that impede the achievement of many poor and minority students. ${ }^{18}$ In a past work, I also explored some of the reasons that these efforts have failed to ensure equal educational opportunity. ${ }^{19}$ In light of this literature, education federalism undoubtedly is not the only factor that has influenced the nation's inability to ensure equal educational opportunity. Nevertheless, it is important to understand the consistent ways in which education federalism has contributed to the ineffectiveness of efforts to ensure equal educational opportunity as scholars propose new avenues to achieve this paramount goal. In addition, in both past and future work, I argue that the nation should consider embracing a new framework for education federalism that would enable the nation to more effectively achieve its goals for public schools. ${ }^{20}$ Understanding how education federalism has hindered past reforms is an essential part of exploring how education federalism should be reshaped.

In addition, this Article also briefly highlights that when the Supreme Court and Congress limited reforms to advance equal educational opportunity, they harkened back to an extinct model of dual federalism and failed to acknowledge that, since the New Deal, the nation has moved to the increasing jurisdictional partnerships that are oftentimes labeled cooperative federalism. ${ }^{21}$ In this way, this Article engages some of the federalism scholarship. Furthermore, this Article notes that one possible explanation for some of the Court's decisions is that the Court may be claiming that federalism prevents it from acting when the Court lacks the will or

18. See, e.g., ReBELL \& WolfF, supra note 7, at 13-14 (noting that the lack of a comprehensive welfare system in the United States has created barriers to success for low-income and minority children); RYAN, supra note 7, at 272 ("Middle-income and more affluent families, mostly white, have largely walled themselves off in separate school districts, leaving to others the task of educating low-income students, most of whom are African-American or Hispanic. For fifty years, the law and politics of educational opportunity have operated to protect the schools behind those walls."); Erwin Chemerinsky, The Deconstitutionalization of Education, 36 LoY. U. CHI. L.J. 111, 111-12 (2004) (discussing the failure of public officials to address school segregation and school inequality due to political unpopularity of "any systematic attempt to deal with education").

19. Kimberly Jenkins Robinson, The Case for a Collaborative Enforcement Model for a Federal Right to Education, 40 U.C. DAVIS L. REV. 1653, 1660-81 (2007).

20. See Robinson, supra note 15, at 433; Kimberly Jenkins Robinson, Reconstructing Education Federalism (Apr. 6, 2013) (unpublished manuscript) (on file with author).

21. Erin Ryan, Federalism and the Tug of War Within, at xiv (2011); Robert A. Schapiro, Polyphonic Federalism: Toward the Protection of Fundamental RIghtS 6 (2009). 
an interest in ensuring that equal educational opportunity becomes a reality for all schoolchildren. Although it would be impossible to confirm if this explanation is accurate, this Article identifies the evidence that suggests that this behavior by the Court may be occurring. After noting this possibility, this Article then takes the Court at its word that education federalism is driving its decisions while exploring the ramifications of the Court's decisions for equal educational opportunity.

This Article proceeds in three parts. Part I examines how education federalism functioned as one of the critical impediments to school desegregation. Part II analyzes how education federalism has handcuffed the reach of school finance litigation. Part III critiques how education federalism has undermined the effectiveness of NCLB. This analysis reveals how the interrelated interests in maintaining the current balance of power between the federal and state governments and in preserving local control of education have limited the effectiveness of these reforms. By examining how education federalism has served as one of the central obstructions to reforms that sought to ensure equal educational opportunity, this Article concludes that future efforts to advance equal educational opportunity must undertake an analysis of how education federalism can be restructured to support all children receiving an equal opportunity to obtain an excellent education.

\section{EDUCATION FEDERALISM AND SCHOOL DESEGREGATION}

School desegregation served as a vehicle for ending the secondclass citizenship of African Americans that Plessy v. Ferguson's separate-but-equal policy sanctioned. ${ }^{22}$ The Court's decision in Brown v. Board of Education (Brown $I)^{23}$ struck down segregated schools as unconstitutional under the Equal Protection Clause.24 Yet, the implementation of this decision was eventually hampered by a variety of factors, including massive resistance. ${ }^{25}$ To understand how the Court privileged education federalism over the equal educational opportunity that school desegregation sought to ensure, this Part first describes the Court's eventual demanding interpretation of the Brown decisions that required integrated schools and an elimination of all traces of discrimination.

This Part then identifies the key desegregation decisions that reveal two intimately interrelated education federalism interests that influenced the decisions that substantially limited the

22. See Plessy v. Ferguson, 163 U.S. 537, 550-52 (1896), overruled by Brown v. Bd. of Educ. (Brown I), 347 U.S. 483 (1954); RICHARD KLUGER, SimPLE JUSTICE: THE HISTORY OF BROWN V. BOARD OF EDUCATION AND BLACK AMERICA'S STRUGGLE FOR EQUALITY 709, 748 (1976).

23. 347 U.S. 483.

24. Id. at 488,495 .

25. See KLUGER, supra note 22 , at 751. 
implementation of effective desegregation plans. First, the Court repeatedly noted the importance of local control of education and that it did not want desegregation to interfere with this important tradition of American education. Second, the Court did not want to disrupt the existing balance of power between the federal and state governments regarding education. Ultimately, the Court concluded in these cases that these interests outweighed the interest in ensuring that the plaintiffs could attend desegregated schools offering equal educational opportunity. Thus, they reflect the Court's deliberate placement of education federalism above equal educational opportunity on the hierarchy of interests within American education and society. ${ }^{26}$ The lower courts took note of the Court's preferences and its focus on local control and were encouraged to terminate desegregation orders. ${ }^{27}$

Finally, this Part concludes by acknowledging that the Supreme Court's 2007 decision in Parents Involved in Community Schools $v$. Seattle School District No. $1^{28}$ may plausibly be read to suggest that education federalism was simply used as a convenient cover for a Court that lacked a strong commitment to effective school desegregation. However, a plausible alternative reading of the decision acknowledges that education federalism remained important but was outweighed by an interest in ending the use of racial classifications.

\section{A. How Education Federalism Impeded Effective School Desegregation}

The Court's 1954 decision in Brown I insisted that educational opportunity must be provided "on equal terms" and that segregation of educational facilities had "no place" in American society. ${ }^{29}$ In reaching this decision, the Court noted the importance of education

26. As will be discussed in Part I.B, the Court's most recent decision regarding school integration departed from its prior insistence on local control of schools. See Parents Involved in Cmty. Sch. v. Seattle Sch. Dist. No. 1, 551 U.S. 701, 732-35 (2007) (striking down two voluntary school integration efforts that considered the race of students because it found that the plans were not narrowly tailored to achieve a compelling state interest); James E. Ryan, The Real Lessons of School Desegregation, in From ScHOOLHOUSE TO COURTHOUSE, supra note 16, at 89 (noting that this decision represents a departure from the Court's prior insistence on local decision making of schools). Although the decision does not offer local control of schools as the reason for doing so, like the desegregation cases discussed in the text, the decision consistently assigns a low priority to integrated schools and the equal educational opportunity that such schools can provide. See Robinson, supra note 16, at 838-39.

27. See Bradley W. Joondeph, Skepticism and School Desegregation, 76 WASH. U. L.Q. 161, 166 (1998); Ronald Turner, The Voluntary School Integration Cases and the Contextual Equal Protection Clause, 51 How. L.J. 251, 295-96 (2008).

28. 551 U.S. 701 (2007).

29. Brown I, 347 U.S. at 493-95. 
and the harms that segregation inflicted upon African American schoolchildren. ${ }^{30}$ In so doing, the Court opined that equal educational opportunity required desegregated schools.

However, this unequivocal condemnation of segregation was quickly undermined in 1955 when the Court, in Brown II, explained that after districts had made "a prompt and reasonable start toward full compliance," school districts could desegregate "with all deliberate speed." ${ }^{31}$ The Court's decision in Brown II also invited delays in desegregation by placing school districts that violated the Constitution in charge of developing the appropriate remedy for the segregation and by failing to issue guidance on the scope of the desegregation obligation, the timing by which desegregation must be completed, and the appropriate remedy for noncompliant districts. ${ }^{32}$ Despite making it clear that open defiance was unacceptable, ${ }^{33}$ the Court's decisions and inactions for over a decade after Brown I worsened the delay sanctioned by Brown II. ${ }^{34}$ In response to the Court's gradualism and limited support for desegregation from the executive branch, school districts adopted a variety of tactics to forestall school desegregation and maintain the status quo. ${ }^{35}$ Although the pace of desegregation slowly began to increase a decade after the Brown decisions, a mere one percent of African American students were enrolled in desegregated schools in the South at the time. ${ }^{36}$ Some scholars contend that without its own enforcement authority or any congressional action, and with limited presidential support, the Court lacked the authority and the inclination to go beyond this limited change. ${ }^{37}$

The glacial pace of desegregation and the civil rights movement eventually led the legislative and executive branches to demand effective school desegregation. ${ }^{38}$ Congress passed the Civil Rights

30. Id. at $493-94$.

31. Brown v. Bd. of Educ. (Brown II), 349 U.S. 294, 300-01 (1955).

32. See Robinson, supra note 16 , at 798.

33. See, e.g., Cooper v. Aaron, 358 U.S. 1 (1958).

34. Robinson, supra note 16 , at 802 . For a discussion of the ways that Brown $I I$ and the Court's actions and inactions slowed the process of school desegregation, see id. at 797-803.

35. See id. at 800 . For a discussion of the ways that school districts delayed and avoided school desegregation after Brown II, see id. at 802-03.

36. See Michael J. Klarman, From Jim Crow to Civil Rights: The Supreme Court and the Struggle for Racial Equality 349 (2004); Gerald N. Rosenberg, The Hollow Hope: Can Courts Bring About Social Change? 52 (2d ed. 2008).

37. See Michael J. KLARMan, BRown V. BoARd of EDUCATION AND THE Civil Rights Movement 123 (2007); Charles J. Ogletree, JR., All Deliberate SpeED: Reflections ON THE First Half CentuRy of BROWN $v$. BoARD of EDUCATION 124 (2004); STEPHEN L. WASBY ET AL., DESEGREGATION FROM BROWN TO ALEXANDER 124 (1977).

38. See KIARMAN, supra note 37, at 101, 123-24; RYAN, supra note 7, at 59; Robinson, supra note 16 , at 807. 
Act of 1964 and authorized the Attorney General to initiate action against a school district that denied admission to a school on the basis of race or otherwise violated equal protection of the laws. ${ }^{39}$ The Department of Health, Education, and Welfare ("HEW") issued guidance in 1965 requiring districts to take action that would create integrated schools, but this guidance initially emphasized whether school officials were acting in good faith and permitted the use of freedom of choice plans that were typically ineffective. ${ }^{40}$ After the Court's decision in Green v. County School Board of New Kent County, ${ }^{41}$ which is described below, HEW subsequently strengthened its guidance to forbid the use of freedom of choice if it failed to eliminate the vestiges of segregation. 42

The Court also eventually demanded reliable and long-standing results from desegregation plans in the 1968 Green decision and the 1971 decision in Swann $v$. Charlotte-Mecklenburg Board of Education. 43 In Green, the Court finally demanded that school districts end the delays in desegregation and immediately implement an effective plan. ${ }^{44}$ The Court clarified school districts' desegregation obligation by identifying six areas that must be desegregated: faculty, staff, the assignment of students to particular schools, extracurricular activities, facilities, and transportation. ${ }^{45}$ In defining the scope of the obligation of school districts, the Court clarified that districts must create integrated schools that eliminated all of the harmful effects of segregation and forbade subsequent discrimination. ${ }^{46}$ Green signaled that desegregation plans would be measured based on their results and that integrated schools were the ultimate goal. ${ }^{47}$

Swann further emphasized the importance of results by sanctioning the use of ratios to guide desegregation, urging the elimination of one-race schools whenever possible, approving of revising attendance zones, and upholding busing as a desegregation tool when busing did not impair the educational experience or

39. 42 U.S.C. $\S 2000$ (c)-6(a) (2006). The statute also forbids recipients of federal financial assistance from discriminating on the basis of race, color, or national origin. Id. $\S 2000$ (d).

40. See Robinson, supra note 16 , at 807 .

41. 391 U.S. 430 (1968).

42. See Robinson, supra note 16 , at 807.

43. 402 U.S. 1 (1971).

44. Green, 391 U.S. at 439.

45. Id. at 435 .

46. Id. at $438 \&$ n.4, 442 . Given these requirements, the Court upheld the plaintiffs' challenge to a freedom-of-choice plan that ostensibly allowed students to attend a school of their choice because under the plan, eighty-five percent of the African American students in the district were still attending all-African American schools. Id. at 437, 441.

47. See Robinson, supra note 16 , at $805-07$. 
health of schoolchildren. ${ }^{48}$ Both Green and Swann were crucial in providing much-needed guidance on the scope of the obligation to desegregate and the necessity of immediate implementation of desegregation plans that created integrated schools. ${ }^{49}$ Ultimately, the Civil Rights Act of 1964, enforcement action by HEW, and Green and Swann notified school districts that they must end the delay and avoidance tactics of the past and resulted in numerous judicial desegregation decrees. ${ }^{50}$

Yet, federal support for meaningful desegregation proved to be quite short lived. Less than a year after Green, the nation elected Richard Nixon to serve as President, and, once in office, he upheld his campaign promise to slow the pace of school desegregation. ${ }^{51} \mathrm{He}$ ordered both HEW and the Department of Justice to pull back on their desegregation efforts and to contest the position of the NAACP in some desegregation litigation. Nixon's election as President ended the very short time frame in which all three branches of government acted aggressively to ensure effective school desegregation. 52

The Court's position also shifted shortly thereafter, and it began to privilege education federalism over the Court's prior goal of an effective desegregation plan that sought to ensure equal educational opportunity. In 1974, the Court's decision in Milliken v. Bradley (Milliken I) erected what proved to be a virtually insurmountable barrier to effective desegregation in many northern districts. ${ }^{53}$ In Milliken I, the Court overturned a lower court desegregation plan for the Detroit public school system that included an interdistrict remedy. ${ }^{54}$ The lower courts found that the federal government, the school district, and the state of Michigan had intentionally created segregated schools; the courts responded by implementing a remedial interdistrict plan because an intradistrict plan would be ineffective and would effectively annul the decision in Brown.55 The Supreme Court rejected the plan and held that an interdistrict remedy could only be implemented if the neighboring districts or the state had committed acts that intentionally segregated students

48. Swann, 402 U.S. at $16,25-31$.

49. For a full discussion of the importance of Green and Swann, see Robinson, supra note 16, at 805-09.

50. See KLARMAN, supra note 37 , at 123-24; Robinson, supra note 16 , at $810-11$.

51. See RYAN, supra note 7, at 59-60.

52. Id. at 59 .

53. See generally Milliken v. Bradley (Milliken I), 418 U.S. 717 (1974). For an extensive discussion of the barriers that Milliken $I$ created for integration, see RYAN, supra note 7, at 105-08; Robinson, supra note 16, at 813-19.

54. Milliken $I, 418$ U.S. at $746-48$.

55. See id. at 724-25; Bradley v. Milliken, 484 F.2d 215, 249 (6th Cir. 1973) (en banc), rev'd, 418 U.S. 717. 
across districts and thereby committed an interdistrict constitutional violation. ${ }^{56}$

The Court's rejection of an effective desegregation plan emphasized two closely interrelated concerns that implicate education federalism. First, the Court heralded the importance of local control of education. ${ }^{57}$ The Court rejected the district court's willingness to treat district lines as creatures of administrative ease because the lower court's approach was "contrary to the history of public education in our country." 58 Indeed, in the Court's view, "[n]o single tradition in public education is more deeply rooted than local control over the operation of schools; local autonomy has long been thought essential both to the maintenance of community concern and support for public schools and to [the] quality of the educational process." 59 The Court characterized the education system in Michigan as one that provided extensive local control in a fashion similar to other states 60 -a characterization that Justice Marshall in dissent vociferously challenged ${ }^{61}$-and noted that the proposed remedy would disrupt the organization of school districts by consolidating fifty-four districts into one large school district. ${ }^{62}$

Second, the Court's opinion also reflected its concerns about substantially altering the balance of power between the federal and state governments as it relates to education. In raising numerous concerns about how the proposed new school district would be governed, the Court stated that it was "obvious from the scope of the interdistrict remedy itself that absent a complete restructuring of the laws of Michigan relating to school districts the District Court will become first, a de facto 'legislative authority' to resolve these complex questions, and then the 'school superintendent' for the entire area."63 Such an arrangement would dramatically shift the balance of power between the federal government and state and local governments - a change that the Court undoubtedly viewed as undesirable.

Milliken I serves as one of the primary examples of how the Court privileged the current understanding of education federalism over the equal educational opportunity that Brown I sought to guarantee. Numerous scholars have noted the near-fatal impact of

56. Milliken I, 418 U.S. at 744-47.

57. See id. at 741.

58. Id.

59. Id. at $741-42$.

60. See id. at 742-43. The Court reached this conclusion "despite the fact that school districts in Michigan were creatures of the state, not the local, government ...." RYAN, supra note 7, at 101-02.

61. See Milliken I, 418 U.S. at 793-97 (Marshall, J., dissenting).

62. Id. at $742-43$ (majority opinion).

63. Id. at $743-44$. 
Milliken I on desegregation. ${ }^{64}$ The decision removed the possibility of developing effective remedies in many districts throughout the North and West because the districts educated an insufficient number of white students to create integrated schools. ${ }^{65}$ Only a small handful of districts could prove an interdistrict violation. ${ }^{6}$ Despite the fact that the Court had held in Green that districts had a constitutional obligation to remedy segregation by creating integrated schools, 67 the schoolchildren in the overwhelming majority of districts in the North and West did not receive an integrated education. ${ }^{68}$

Several additional Supreme Court desegregation decisions also continued to exalt the Court's understanding of education

64. See, e.g., RYAN, supra note 7, at 105 ("It is difficult to exaggerate the consequences of Milliken, which is easily the most important desegregation decision aside from Brown.... On the whole,... suburban school districts received a pass from busing plans. Without the participation of the suburbs, busing was bound to be a failure." (footnotes omitted)); Joondeph, supra note 27, at 164; Robinson, supra note 16, at 814 ("Milliken I erected an almost uniformly insurmountable barrier to interdistrict remedies ...."); Id. at 818-19 $\mathrm{nn}$.20910 (citing scholars who argue that Milliken I was one of the primary causes of desegregation's failure).

65. Molly S. McUsic, The Law's Role in the Distribution of Education: The Promises and Pitfalls of School Finance Litigation, in LAW AND SCHOOL REFORM: Six Strategies fOR Promoting Educational EqUiTy 88, 102 (Jay P. Heubert ed., 1999).

66. See RYAN, supra note 7, at 105 (noting that only four metropolitan areas-Little Rock, Indianapolis, Wilmington, and Louisville-ordered interdistrict busing, St. Louis adopted interdistrict busing in a desegregation settlement, and a few additional districts adopted busing because the city and suburbs were located in the same school district).

67. See Green v. Cnty. Sch. Bd. of New Kent Cnty., 391 U.S. 430, 438 \& n.4, 442 (1968).

68. See Chemerinsky, supra note 18 , at 118 ; Robinson, supra note 16 , at 816. In this way, the Court's protection of local control in Milliken I preserved the autonomy of predominantly white suburban neighborhoods and the preferences of middle-income whites. RYAN, supra note 7, at 103-04; see also Liu, supra note 16, at 726 . Furthermore, the negative impact of Milliken $I$ s preference for local control over integrated schools was not mitigated by Milliken Ir's approval of an alternative desegregation plan that included compensatory programs such as a remedial reading program and professional development for teachers and administrators. See Milliken v. Bradley (Milliken $I I), 433$ U.S. 267, 272-77, 287-88 (1977). Numerous school districts sought Milliken II funding as an alternative to busing, because busing was futile due to the high concentrations of minority students within a district. See Ryan, supra note 26 , at 73,84 . However, Milliken $I I$ funding proved ineffective in making a substantial impact on these schools and did not substantially improve student achievement. See RYAN, supra note 7, at 108, 159. Moreover, the Milliken II opinion reaffirmed the Court's emphasis in Milliken I on local control of schools as one of the paramount concerns of a district court when it fashioned a remedy for intentional segregation. See Milliken II, 433 U.S. at 280-81 ("[F]ederal courts in devising a remedy must take into account the interests of state and local authorities in managing their own affairs, consistent with the Constitution."). 
federalism at the expense of the equal educational opportunity that effective school desegregation would have provided. In Board of Education of Oklahoma City Public Schools, Independent School District No. 89 v. Dowell, ${ }^{69}$ the Court held that federal courts assessing whether a school district should be released from court supervision should determine whether the district had complied with the desegregation decree in good faith and "whether the vestiges of past discrimination had been eliminated to the extent practicable."70 The shift in emphasis away from maintaining integrated schools is evident from the Court's emphasis on this new standard and its silence about the large number of single-race schools that would result under the school board's proposed neighborhood assignment plan. ${ }^{71}$

In stating its reasons for adopting this more lenient standard for assessing the implementation of desegregation, the Court in Dowell once again trumpeted both the importance of local control of the schools and maintaining the balance of power between federal and state authorities as the principal rationales for its decision. ${ }^{72}$ By changing the standard for assessing a desegregation plan to emphasize the good faith of the school districts and the practicalities of implementation, the Court privileged the federalism interests over the Court's prior insistence in Green and Swann on an effective plan that created integrated schools and uprooted all traces of unlawful segregation, including single-race schools. ${ }^{73}$ The effect of the Court's decision was to sanction termination of court oversight of a desegregation decree if a school district attempted unsuccessfully to integrate its schools. ${ }^{74}$ Following the opinion, research revealed that other federal courts accepted inadequate results from

69. 498 U.S. 237 (1991).

70. Id. at $249-50$.

71. See Robinson, supra note 16 , at $823-24$. Indeed, under the plan that the school district sought to implement, over half of the district's African American students would attend schools that enrolled over ninety percent African American students, and more than half of the elementary schools would be over ninety percent single-race schools. Dowell, 498 U.S. at 242; Dowell v. Bd. of Educ. of Okla. City Pub. Sch., Indep. Dist. No. 89, 890 F.2d 1483, 1487 (10th Cir. 1989), rev'd, 498 U.S. 237; Robinson, supra note 16, at 822-23. This swift return to a substantial number of single-race schools prompted the Tenth Circuit to reject the school district's proposed plan. Dowell, 498 U.S. at 243-44. Once the Court sent the case back to the lower court, the lower court determined that the school district had met the new standard and the district's neighborhood attendance plan resulted in the anticipated return to more than half one-race elementary schools. See Bradley W. Joondeph, Missouri v. Jenkins and the De Facto Abandonment of Court-Enforced Desegregation, 71 WASH. L. REV. 597, 655 (1996).

72. See Dowell, 498 U.S. at 248.

73. See Swann v. Charlotte-Mecklenburg Bd. of Educ., 402 U.S. 1, 15, 26 (1971); Green v. Cnty. Sch. Bd. of New Kent Cnty., 391 U.S. 430, 437-39 (1968).

74. See Parker, supra note 16 , at $1165-67$. 
desegregation plans, including accepting segregation of staff and faculty that tracked the racial concentration of students within a school that was undoubtedly within the control of school districts. ${ }^{75}$ Thus, as in Milliken I, the Court in Dowell elevated the interests of education federalism over and above the interest in ensuring that all students receive equal educational opportunity. ${ }^{76}$

The Court similarly made education federalism interests paramount to equal educational opportunity in its decision in Freeman v. Pitts. ${ }^{77}$ In Freeman, the Court considered whether school districts must desegregate all of the Green factors simultaneously and maintain desegregated schools for a few years as the lower court had required. ${ }^{78}$ The Court rejected any need for a school district that had intentionally segregated students to be completely desegregated for any length of time and instead held that federal courts could release school districts from court oversight of the Green factors in an incremental fashion. ${ }^{79}$ Like in its opinion in Dowell, the Court underscored the consideration of the good faith compliance with court orders rather than the district's success at effectively eliminating all vestiges of discrimination. ${ }^{80}$

What is remarkable about Freeman is that the Court openly acknowledged the continued effects of past discrimination but disclaimed any need or responsibility for the school board to remedy those effects despite prior opinions that placed this responsibility on intentionally discriminatory school boards. ${ }^{81}$ The Court unequivocally admitted that "vestiges of past segregation by state decree do remain in our society and in our schools. Past wrongs to the black race, wrongs committed by the State and in its name, are a stubborn fact of history. And stubborn facts of history linger and persist." 82 Nevertheless, the Court opined that the good faith compliance of the school board served as a sufficient basis to terminate the board's responsibility for racial segregation in the district and to shift that responsibility to demographic factors

75. See Robinson, supra note 16 , at 824 .

76. See Parker, supra note 16, at 1166,1178 (noting that the Court used the importance of local control of schools as a reason to absolve or pardon the segregation that remained in the schools); Robinson, supra note 16, at 824-25 ("The emphasis on local control exempted defendants from having to address persistent racial segregation and expressed a 'value choice' by the Court that the need to end court-supervised desegregation was paramount and that efforts to desegregate could be abandoned." (footnotes omitted)).

77. 503 U.S. 467,489 (1992).

78. See id. at 471 .

79. Id.

80. See id. at 491-92.

81. See Swann v. Charlotte-Mecklenburg Bd. of Educ., 402 U.S. 1, 15 (1971); Green v. Cnty. Sch. Bd. of New Kent Cnty., 391 U.S. 430, 438 \& n.4 (1968).

82. Freeman, 503 U.S. at 495. 
beyond the district's control.83 The Court did not explain how the mere passage of time heals the ongoing effects of past discrimination. Instead, it appears that the Court simply believed that the time for desegregation had come and gone and that the nation needed to move on to other more pressing matters. ${ }^{84}$

In upholding the validity of partial withdrawal of court supervision over desegregating school districts, the Court again emphasized the importance of returning the school district to local control.85 Indeed, although the Court acknowledged that court intervention in school desegregation seeks both to remedy the constitutional violation and to restore state and local authority over the schools, the Court emphasized the primacy of the local control objective by describing local control as "the ultimate objective" of school desegregation. ${ }^{86}$ The Court sanctioned incremental termination of court supervision as one way to uphold this "vital national tradition." 87 Indeed, the Court opinion makes clear that the value of local control of schools outweighed the need to hold the school district responsible for the effects of its discrimination or to maintain a completely desegregated school district for even one day, let alone one school year. ${ }^{88}$ Thus, Freeman provides another example of the Court privileging education federalism interests over an effective desegregation plan that would offer students equal educational opportunity.

83. See Parker, supra note 16, at 1170-71; James E. Ryan, The Limited Influence of Social Science Evidence in Modern Desegregation Cases, 81 N.C. L. REV. 1659, 1671 (2003). The Court justified incremental termination of court supervision by disclaiming any necessary connection between demographic shifts and an intentional constitutional violation. See Freeman, 503 U.S. at 496. The Court explained that as years increase since the violation, the likelihood decreases that the violation caused existing racial imbalances in schools. Id.

84. In contrast, the Justices who concurred in the judgment that districts could be incrementally released from court supervision criticized the majority's failure to recognize that the school district's maintenance of African American schools and white schools may have influenced the demographic changes within the district. See Freeman, 503 U.S. at 515 (Blackmun, J., concurring). The concurring Justices further noted that the school district remained responsible for remedying the effect of segregation on the school system given the Court's prior requirements in cases like Green that demanded that school boards eliminate all effects of their prior discrimination. See id. at 511,514 .

85. See id. at 489 (majority opinion) ("Partial relinquishment of judicial control, where justified by the facts of the case, can be an important and significant step in fulfilling the district court's duty to return the operations and control of schools to local authorities.”).

86. See id. (emphasis added).

87. See id. at 489-90 (quoting Dayton Bd. of Educ. v. Brinkman, 433 U.S. 406, 410 (1977)).

88. See id. at 509 (Blackmun, J., concurring). 
Finally, the Court's decision in Missouri v. Jenkins ${ }^{89}$ revealed a similar preference for education federalism interests over an effective desegregation plan. In Jenkins, the lower courts had ordered the state to remedy its intentional segregation of students in the Kansas City, Missouri, school district and the resulting white flight and substandard educational achievement by improving the educational opportunities in the district so that white students would be voluntarily attracted back to the district. 90 The lower courts found that an efficacious desegregation remedy was unattainable without an interdistrict approach that drew white students into the mostly minority school district. ${ }^{91}$ Nevertheless, the Supreme Court overturned the plan because the goal of attracting students back to the district-even on a voluntary basiswas not justified in the absence of evidence that the state had intentionally segregated students between districts..$^{92}$

Like Milliken, Dowell, and Freeman before it, the Court in Jenkins emphasized the importance of local control of education rather than lasting and meaningful desegregation. ${ }^{93}$ The Court noted that the programs required by the lower courts to improve the school district and its attractiveness to white students in surrounding school districts, such as raising teacher salaries and improving the quality of the education programs, increased the school district's reliance on the state and ultimately on the district court for oversight.94 This reliance undermined the "vital national tradition" of local control over schools. ${ }^{95}$ Rather than proposing an alternative effective remedy that would integrate the heavily minority school district, the Court invalidated the remedial programs and efforts to improve the schools and the students' test scores while repeatedly reminding the federal courts that they must work to reinstate state and local authority over the school system once the system is in compliance with the Constitution. ${ }^{96}$

The emphasis on local control of education in the Court's decisions in Milliken, Dowell, Freeman, and Jenkins harkened back to dual federalism's insistence that the federal government and the

89. 515 U.S. 70 (1995). 70.

90. Jenkins v. Missouri, 11 F.3d 755, 759 (8th Cir. 1993), rev'd, 515 U.S.

91. See Jenkins, 515 U.S. at $90-91,94$.

92. See id. at 94-99.

93. See id. at 98-99, 102.

94. Id. at 99 .

95. Id.

96. See id. at 99, 102. However, even if one accepts that local control of education was the norm when Milliken $I$ was decided-a contention that I dispute in the text, see infra text accompanying notes 98-103-other research has demonstrated that, by the time that Jenkins was rendered, local control no longer served as the principal organizing principle for school governance in the United States. See Liu, supra note 16, at 731. 
state governments divide authority based on subject matter. 97 However, consistent with the demise of dual federalism and the rise of cooperative federalism, 98 education law and policy at the time of these decisions had evolved such that, at a minimum, federal authority had been sanctioned and deemed essential to ensuring equal educational opportunity. This occurred not only through the landmark Brown decisions and other desegregation decisions that used federal power to ensure integrated schools but also through the Elementary and Secondary Education Act of 1965 ("ESEA") and its reauthorizations that marshaled federal authority to assist lowincome students; ${ }^{99}$ numerous additional federal education laws on issues of equal opportunity for girls and women, ${ }^{100}$ disabled students, ${ }^{101}$ and English language learners; ${ }^{102}$ and federal enforcement of these laws by the U.S. Department of Education. In the Milliken, Dowell, Freeman, and Jenkins decisions, this insistence on a dualist understanding of education failed to protect the right to attend a nondiscriminatory school system, just as it has failed to protect individual rights in other areas. 103

These decisions-along with several other factors, such as the retreat of many white and middle class families to the suburbs and the intermittent support for federal action by the executive and legislative branches-have led to resegregation of many of the nation's schools.104 Despite growing diversity in the public school population, school segregation has been increasing in recent decades

97. RYAN, supra note 21; SCHAPIRO, supra note 21 , at 3 .

98. See RYAN, supra note 21.

99. See Derek W. Black, The Congressional Failure to Enforce Equal Protection Through the Elementary and Secondary Education Act, 90 B.U. L. REV. 313, 336-39 (2010) (noting that the original intent and structure of Title I was to provide assistance to low-income students but also analyzing how Congress diluted and undermined this purpose over time).

100. See Title IX of the Education Amendments of 1972, 20 U.S.C. $\S 1681$ (2006).

101. See Individuals with Disabilities Education Act, 20 U.S.C. $\$ 1400$ (2006) (previously Education for All Handicapped Children Act of 1975, Pub. L. No. 94-142, 89 Stat. 773).

102. See Lau v. Nichols, 414 U.S. 563, 566-68 (1974) (noting that Title VI of the Civil Rights Act of 1964 and HEW guidelines interpreting that law required school districts receiving federal financial assistance to rectify any language barrier that impeded English language learners' access to education).

103. See SCHAPIRO, supra note 21 (noting how reliance on dual federalism has led to "mistaken rulings and bad policy" and has been used as a reason for striking down "statutes keeping guns out of schools, protecting women from violence, preserving intellectual property from state infringement, and requiring compensation for state employees for workplace wrongs ranging from age and disability discrimination to failure to honor minimum wage and overtime requirements" (footnotes omitted)).

104. Gary Orfield ET al., The Civil Rights Project, $E$ Pluribus ... Separation: DeEpening Double Segregation For More STUDENTS, at xvii-xix (2012). 
and has led to increasingly racially isolated schools. ${ }^{105}$ For instance, the percentage of Latino and African American students who attend schools composed of $90 \%-100 \%$ minority students has consistently grown since the 1991-92 school year. ${ }^{106}$ In the 2009-10 school year, 43.1\% of Latino students and $38.1 \%$ of African American students attended schools in which $90 \%-100 \%$ of the students are minorities, up from $33.9 \%$ and $32.7 \%$ respectively in 1991-92.107 In addition, the percentage of poor students has grown significantly in the last three decades, with the average African American and Hispanic student attending a school that was one-third poor students in the early 1990s while today these students typically attend a school with two-thirds poor students. ${ }^{108}$ These trends are made even more troubling when one considers research that consistently documents the harms of racial isolation and the benefits of diverse schools. ${ }^{109}$ Furthermore, research reveals that concentrated poverty has a stronger relationship to inequality in education than racial segregation. 110 Education federalism contributed to these troubling trends by serving as one of the impediments to school desegregation.

The next Subpart considers whether the Supreme Court's decision in Parents Involved establishes that the Court's professed concerns about education federalism merely disguised its lack of interest in meaningful desegregation.

\section{B. Parents Involved and Education Federalism}

The Court's decision in Parents Involved in Community Schools v. Seattle School District No. 1 can be viewed as a departure from the Court's prior interest in preserving local control of public schools.111 In Parents Involved, the Court struck down voluntary student assignment plans that were adopted by the school districts in Seattle and Louisville because the districts failed to prove that the use of race was necessary and that the districts had given goodfaith consideration to race-neutral alternatives. ${ }^{112}$ The decision departs from past decisions' emphasis on local control because the Court refused to defer to the decision of the school boards on their

105. Id. at $75-76$.

106. See id. at 19 tbl.3.

107. See id. at 19 tbl.2.

108. $I d$, at 76 .

109. See Kimberly Jenkins Robinson, The Constitutional Future of RaceNeutral Efforts to Achieve Diversity and Avoid Racial Isolation in Elementary and Secondary Schools, 50 B.C. L. REv. 277, 327-35 (2009).

110. See ORFIELD ET AL., supra note 104, at 76 (citing Sean F. Reardon et al., The Changing Structure of School Segregation: Measurement and Evidence of Multiracial Metropolitan-Area School Segregation, 1989-1995, 37 DEMOGRAPHY $351(2000))$.

111. See Ryan, supra note 26 , at 73,89 .

112. Parents Involved in Cmty. Sch. v. Seattle Sch. Dist. No. 1, 551 U.S. 701, 733-35 (2007). 
need for the plan and the ineffectiveness of race-neutral alternatives, despite being urged to do so in numerous briefs. ${ }^{113}$ The refusal to reaffirm local control may suggest that the Court's prior interest in preserving local control may have simply represented a convenient cover for its lack of willingness to ensure effective school desegregation. ${ }^{114}$ Indeed, elsewhere I have argued that Parents Involved merely continued the Court's affirmation of a return to segregated schools. ${ }^{115}$

Nevertheless, assuming for the sake of argument that the Court's interest in the preservation of state and local control was genuine in prior cases, an alternative interpretation of Parents Involved also should be considered. Parents Involved may simply reveal that even the strong preference for local control does not outweigh the Court's increasingly stronger preference for an end to the use of race-based classifications. ${ }^{116}$ The plurality admonished districts to end the use of classifications when it stated that "[t]he way to stop discrimination on the basis of race is to stop discriminating on the basis of race." 117 Although Justice Kennedy wrote separately to reaffirm that districts may continue to adopt student assignment plans to reduce racial isolation and promote diversity, ${ }^{118}$ he has yet to review an affirmative action plan that meets the highly demanding criteria that he applies to race-based action. ${ }^{119}$ Indeed, his questions in the Fisher $v$. University of Texas at Austin ${ }^{120}$ oral argument suggest that he will vote to strike down the use of race in that case even though it was limited to a small number of students and adopted only after the University of Texas

113. See, e.g., Brief of the NAACP as Amicus Curiae in Support of Respondents at 6, Parents Involved, 551 U.S. 701 (Nos. 05-908, 05-915), 2006 WL 2927073, at *6, *11; Brief of The Nat'l Parent Teacher Ass'n as Amicus Curiae in Support of Respondents at 18, Parents Involved, 551 U.S. 701 (Nos. 05-908, 05-915), 2006 WL 2882699, at *18; Brief of Nat'l Sch. Bds. Ass'n et al. as Amici Curiae in Support of Respondents at 3, Parents Involved, 551 U.S. 701 (Nos. 05-908, 05-915), 2006 WL 2925968, at *3.

114. See Ryan, supra note 26, at 89-91 (noting that the desegregation cases do not prove that the Court cannot accomplish social change but instead show that "the Court was unwilling to press hard to achieve lasting school integration").

115. See Robinson, supra note 16 , at $837-38$.

116. See City of Richmond v. J.A. Croson Co., 488 U.S. 469, 505-06 (1989); Donald Lively, The Constitution, RaCe, and RENEwED Relevance of ORIGINAL INTENT 187 (2008) ("The Court's investment in constitutional color blindness in the late twentieth century was the precursor of growing references to a post-racial society in the early twenty-first century.").

117. Parents Involved, 551 U.S. at 748.

118. See id. at 787-89 (Kennedy, J., concurring).

119. See Adam Liptak, Justices Take Up Race as a Factor in College Entry, N.Y. TiMES, Feb. 22, 2012, at A1.

120. 631 F.3d 213 (5th Cir. 2011), cert. granted, 132 S.Ct. 1536 (2012) (mem.). 
had attempted to achieve diversity through other means. ${ }^{121}$ Under this reading of Parents Involved, ending the use of racial classifications-or one that effectively accomplishes that under Justice Kennedy's approach-outweighed the still-substantial interest in local control.

Ultimately, although one can plausibly read Parents Involved as suggesting that local control did not serve as a paramount interest in the preceding school desegregation cases, the decision does not disprove that local control and maintaining the existing balance of federal and state authority served as important interests that limited the reach of school desegregation. These interests may still have guided the Court's decisions on school desegregation from Milliken I onward. Instead, Parents Involved may reveal that although these interests remain essential, even they must yield to other predominant principles in a particular case.

The next Part explores the influence of education federalism on school finance litigation.

\section{EdUCATION FEDERALISM AND SCHOOL FINANCE LITIGATION}

Once the attention shifted away from school desegregation, some reformers pursued school finance litigation to challenge disparities in educational opportunity. ${ }^{122}$ These reformers scored an initial victory in 1971 in the California Supreme Court's decision in Serrano v. Priest, in which the court held that education was a fundamental interest and that substantial disparities in per-pupil financing in California violated the Federal Equal Protection Clause and its California equivalent. ${ }^{123}$ However, reformers quickly met a roadblock to federal lawsuits on these issues in the U.S. Supreme Court. This Part examines how federalism influenced the Supreme Court's decision to foreclose federal school finance litigation. It then analyzes research that considers whether state school finance reform and litigation have been an effective alternative for ensuring that all students receive equal educational opportunity.

\section{A. Closing the Door to Federal School Finance Litigation}

The Court ruled in its 1973 decision in San Antonio Independent School District v. Rodriguez ${ }^{124}$ that the Constitution did not recognize education as a fundamental right and rejected

121. See Adam Liptak, Justices Weigh Race as a Factor at Universities, N.Y. TIMES, Oct. 11, 2012, at A1.

122. See Melissa C. Carr \& Susan H. Fuhrman, The Politics of School Finance in the 1990s, in EQUTTY AND ADEQUACY IN EDUCATION FINANCE: ISSUES AND PERSPECTIVES 136, 143 (Helen F. Ladd et al. eds., 1999).

123. Serrano v. Priest (Serrano I), 487 P.2d 1241, 1244, 1249 n.11 (Cal. 1971); Serrano v. Priest (Serrano II), 557 P.2d 929, 957-58 (Cal. 1976); see also Carr \& Fuhrman, supra note 122.

124. 411 U.S. 1 (1973). 
plaintiffs' arguments that the Texas school financing scheme discriminated on the basis of wealth. ${ }^{125}$ Mexican American parents of children in schools in the Edgewood Independent School District, a city school district in San Antonio, Texas, sued the state on behalf of minority schoolchildren and those poor children who lived in districts with a relatively low base for property taxes. ${ }^{126}$ The plaintiffs alleged that the Texas school finance system discriminated against a suspect class and infringed upon education as a fundamental right. ${ }^{127}$ They emphasized the wide disparities in perpupil spending throughout the state. ${ }^{128}$ The federal district court held that the Texas system for financing schools violated the Federal Equal Protection Clause because it discriminated on the basis of wealth by allowing wealthier districts to provide a higherquality education while paying lower taxes than less affluent districts. ${ }^{129}$ The lower court found that although Texas claimed that the system promoted local control and the ability of parents to determine how much to spend on their child's education, in reality "the state has, in truth and in fact, limited the choice of financing by guaranteeing that 'some districts will spend low (with high taxes) while others will spend high (with low taxes)."'130

The Supreme Court reversed and held that the Texas scheme neither discriminated on the basis of wealth nor infringed upon a fundamental right. ${ }^{131}$ The Court rejected the wealth discrimination claim because the class, according to the Court, was not clearly defined, nor did the class bear the hallmarks of a suspect class, such as a history of past discrimination or a lack of political power. ${ }^{132}$ The Court further held that the Constitution neither explicitly nor implicitly protected education as a fundamental right and that the importance of education could not render it a fundamental right. ${ }^{133}$ Even though an education is necessary to exercise the right to speak and to vote, the Court noted that the Constitution did not guarantee

125. See id. at $6,18-19,28,35$.

126. Id. at $4-5$.

127. See id. at 17 .

128. See id. at 15. For instance, the Edgewood Independent School District adopted the highest tax rate in the San Antonio area but, given its low property value, was only able to raise $\$ 26$ per pupil and to spend a total of $\$ 356$ per pupil when state and federal funds were added to the local contribution. See id. at 12. In contrast, Alamo Heights, the most property-rich district in San Antonio, raised $\$ 333$ per pupil with a lower tax rate and spent a total of $\$ 594$ per pupil. See id. at 13.

129. See id. at 6; Rodriguez v. San Antonio Indep. Sch. Dist., 337 F. Supp. 280,285 (W.D. Tex. 1971), rev'd, 411 U.S. 1.

130. Rodriguez, 337 F. Supp. at 284 (quoting Van Dusartz v. Hatfield, 334 F. Supp. 870, 876 (D. Minn. 1971)).

131. See Rodriguez, 411 U.S. at 6, 18-19, 28, 35.

132. Id. at 28 .

133. Id. at 33,35 . 
that either right must be exercised to its fullest extent. ${ }^{134}$ Furthermore, the plaintiffs had only alleged a relative deprivation of educational opportunity and had failed to allege an absolute denial of education or that the state had denied each child the chance to obtain "the basic minimal skills necessary for the enjoyment of the rights of speech and of full participation in the political process."135

In the absence of a fundamental right, the Court reviewed the disparities in educational opportunity under the rational basis standard and found that the system rationally advanced local control of education. ${ }^{136}$ The Court explained that in matters of tax policy and education policy, it lacked the expertise to interfere with state and local decisions.137 Given the debates about the relationship between quality and school expenditures, the goals of education, and the proper allocation of authority between state and local governments, the Court noted that wisdom counseled against it imposing constitutional requirements upon the states that could hinder them from discovering possible solutions to the challenges they confront when designing school funding systems. 138 For these reasons, the Court held that the Texas school funding system was rationally related to a legitimate state interest in local control of education. 139

Like the school desegregation cases, the Rodriguez Court relied heavily on two interrelated education federalism interests when it rejected the plaintiffs' claims: maintaining the existing balance of power between the federal and state governments and ensuring local control of schools. 140 The Court indicated that it wanted to maintain the existing balance of power when it noted that the plaintiffs were essentially asking the Court to invalidate the school finance systems in all fifty states. ${ }^{141}$ In rejecting the plaintiffs' claims, the Court acknowledged that, although all equal protection claims implicate federalism, "it would be difficult to imagine a case having a greater potential impact on our federal system than the one now before us." 142 The Court explained that its understanding of the proper allocation of federal and state power also guided its application of the rational basis standard to determine the constitutionality of the existing school finance system. ${ }^{143}$ Furthermore, invalidating the property tax as a means of funding

134. See id. at 36.

135. Id. at 37.

136. See id. at 40, 49-53.

137. See id. at 40-42.

138. Id. at 43.

139. See id. at 54-55.

140. See id. at 42-44, 49-50.

141. See id. at 47-48, 54-55.

142. Id. at 44 .

143. See id. 
schools could implicate the funding of other public services that rely on property taxes. ${ }^{144}$

The Court's opinion also emphasized the nation's long-standing commitment to local control of education and the benefits that it secures for education. According to the Court, local control of education enables communities to create programs that are tailored to the needs of their students. ${ }^{145}$ Like the relationship between the federal government and the state, local control also provides "some opportunity for experimentation, innovation, and a healthy competition for educational excellence." ${ }^{146}$ In fact, the Court claimed that no social issue could benefit more from a variety of viewpoints and approaches than education. ${ }^{147}$ The Court further explained that even though centralization of government represented a growing trend, local oversight of schools has remained one of the hallmarks of the American education system.148

The Court also reaffirmed the freedom of Texas residents to choose a system that favored local control over greater equality. The plaintiffs had acknowledged the numerous benefits of local control but had contended that local control could be preserved while simultaneously narrowing the disparities in educational opportunity that pervaded the system.149 The Court responded that, under the rational basis standard, Texas was not required to choose the least restrictive approach to accomplish its goals. ${ }^{150}$ Instead, given the many benefits of local control of education, the Court noted that Texas residents might justifiably conclude that additional state control over school finances would result in an undesirable increase in state control over school decisions. ${ }^{151}$ The Court also noted its unwillingness to claim that its assessment of the Texas system was superior to that of the educators, scholars, and state lawmakers throughout the nation. ${ }^{162}$ In reaching this conclusion, the Court again chose to preserve education federalism at the expense of equal educational opportunity. ${ }^{153}$

144. See id. at 54 .

145. Id. at 50 .

146. $I d$.

147. Id.

148. See id. at 49.

149. See id. at 50.

150. See id. at 50-51. In rejecting the plaintiffs' contention that the system of financing schools should not depend upon the "happenstance" of the amount of taxable property in each district, the Court responded that all jurisdictional boundaries in taxation schemes are arbitrary and that localities may influence the amount of taxable property by attracting businesses to the locality. See id. at $53-54$.

151. Id. at $51-53$.

152. Id. at 55.

153. See Liu, supra note 16, at 724 (" $[\mathrm{I}] \mathrm{n}$ Rodriguez ... deference to local control led the Court to retreat from the imperative of equal educational opportunity."). 
In privileging the interests of federalism over equal educational opportunity, the Court insulated inequitable disparities in educational opportunity from federal judicial oversight. Instead of considering how these disparities could be addressed, the Court treated these disparities, "however avoidable and 'unjust,' as nothing more than an unfortunate and unactionable byproduct of the 'vital national tradition' of local control."154 This approach fails to account for the vital national interest in equal educational opportunity that the Court recognized in Brown I. ${ }^{155}$

Furthermore, as occurred in the school desegregation decisions, the Rodriguez Court's insistence on the primacy of state and local control of education paints a dualist portrait of education law and policy that did not exist when the Court decided the case..$^{156}$ This dualist portrait fails to protect individual rights and to understand the importance of a federal role in ensuring equal educational opportunity that is evidenced in Brown I, the ESEA, and other federal laws requiring equal educational opportunity. ${ }^{157}$ The five-tofour vote in the case signifies that the dissenting Justices did not share this dualist understanding of education federalism. Instead, the four dissenting Justices concluded that the Texas system did not provide local control to those districts with a low property tax base because "no matter how desirous parents are of supporting their schools with greater revenues, it is impossible to do so through the use of the real estate property tax" given the value of the property within those districts and the state law limits on the tax rate. ${ }^{158}$ Therefore, the Texas funding scheme failed to satisfy the rational basis standard. ${ }^{159}$ In fact, the dissenting Justices concluded that the majority made its equal protection analysis into nothing "more than an empty gesture" because it failed to require Texas to establish how the approach it adopted was rationally related to the goal of local control.160 Numerous scholars agree with the dissenting Justices and contend that Rodriguez was wrongly decided. ${ }^{161}$

154. Id. at 727 (footnote omitted).

155. See Brown v. Bd. of Educ. (Brown I), 347 U.S 483, 493 (1954). 21.

156. See MANNA, Collision CoURSE, supra note 3 , at 5; SCHAPIRo, supra note

157. See supra text accompanying notes 99-103; see also MANNA, Collision Course, supra note 3 , at 5 ("Since the 1960s, developments in federal [education] policy have reflected this equity theme.").

158. San Antonio Indep. Sch. Dist. v. Rodriguez, 411 U.S. 1, 64-67 (1973) (White, J., dissenting) (emphasis added).

159. See id. at 67-68.

160. See id.

161. See, e.g., Chemerinsky, supra note 16 ("The Court held that there is no constitutional right to education and thus that differentials in spending between wealthy and poor school districts within a metropolitan area are constitutionally permissible. If I were to list the most important, and the worst, Supreme Court decisions during my lifetime, Rodriguez would be high on this list."); Thomas Kleven, The Democratic Right to Full Bilingual Education, 7 
Scholars also raise substantial arguments that Rodriguez no longer remains applicable law. Since the Court decided Rodriguez, scholars have noted that even if one agrees with the characterization of the importance of local control that the Court trumpets in the decision, local control of education no longer remains the prevalent approach to education federalism within the United States.162 Instead, numerous scholars have noted the growing centralization of education at the state and federal levels beginning in the 1980s and through NCLB. ${ }^{163}$ Although states only provided a small share of education budgets when Rodriguez was decided, states now serve as the primary funders of education. ${ }^{164}$ Education law scholar Derek Black also has persuasively demonstrated that the federalism concerns that limited the Court's decision in Rodriguez would no longer limit the Court's actions today. ${ }^{165} \mathrm{He}$ further argued that states have already created rights to education that would enable the Court to find that the Equal Protection Clause demands that the states implement their education laws to ensure that districts possess the essential educational resources that they require to provide state-defined rights to education. ${ }^{166}$

Some also have suggested that the need to preserve local control, particularly suburban local control, has been used by the Supreme Court as an excuse for limiting school desegregation and school finance reform. ${ }^{167}$ This suggests that education federalism may simply have been a shield that the Court hid behind when it lacked the will to interpret federal law in a way that would ensure that students enjoyed the equal educational opportunity that Brown

NEv. L.J. 933, 939 (2007); David A.J. Richards, Equal Opportunity and School Financing: Towards a Moral Theory of Constitutional Adjudication, 41 U. CHI. L. REV. 32, 70 (1973) ("If one believes in principled and reasoned constitutional adjudication, Rodriguez must be disappointing, for it is not supported by sound constitutional principles or moral or legal reasoning. The majority could not have reached this decision had it given precise thought to the nature and weight of the moral concept of equal opportunity."). But see Jeffrey S. Sutton, San Antonio Independent School District v. Rodriguez and Its Aftermath, 94 VA. L. REV. 1963, 1977-78 (2008) (arguing that Rodriguez led to school funding reform at the state level).

162. See Black, supra note 10, at 1405-06; Michael Heise, The Political Economy of Education Federalism, 56 EMORY L.J. 125, 131 (2006); James E. Ryan, The Tenth Amendment and Other Paper Tigers: The Legal Boundaries of Education Governance, in Who's in ChaRge Here?: The TANGled Web of SCHOOL GovernaNCE AND POLICY 42, 60 (Noel Epstein ed., 2004).

163. See Black, supra note 10, at 1402-03; Heise, supra note 162; Liu, supra note 16, at 730-31; Ryan, supra note 162 .

164. See Black, supra note 10 , at 1403 .

165. Id. at 1395-1406.

166. See id. at $1405-06$.

167. RYAN, supra note 7 , at 212 ; see also Liu, supra note 16 , at 726. 
$I$ proclaimed was their right. ${ }^{168}$ As noted in Part I.A, proving or disproving the genuineness of the Court's rationale can be quite difficult, although some believe that Parents Involved provides substantial evidence that, in the context of school desegregation, the strong preference for local control was not as genuine as the Court professed in earlier cases. ${ }^{169}$

Yet, if one gives credence to the authenticity of the Court's rationales in these cases, one also can identify several reasons why the Court might genuinely deflect an invitation to uphold remedies that would overturn, or at least significantly alter, the American tradition of state and local control over schools and limited federal power in this arena. First, the Court might honestly believe that it simply is not the institution to decide whether this tradition should continue given its lack of expertise on education issues and its undemocratic nature. 170 Instead, the Court might view the states, or even Congress, as better suited to decide the continuing value of this American tradition. Second, the Court in Rodriguez might have found the split of opinion on pivotal education policy issues-such as whether additional resources would improve student outcomes-as sufficient reason to stay its hand. ${ }^{171}$ Finally, the Court may have believed that it lacked the capacity and resources to accept federal oversight of school desegregation and the nation's school finance systems in perpetuity.

Undoubtedly, a Court that privileged equal educational opportunity over these other competing values could have overcome each of these obstacles. Indeed, numerous scholars have argued that the Court should have decided the school desegregation cases and Rodriguez differently, ${ }^{172}$ and I find many of their arguments

168. Brown v. Bd. of Educ. (Brown I), 347 U.S. 483, 493 (1954).

169. See Suzanne Eckes, Public School Integration and the 'Cruel Irony' of the Decision in Parents Involved in Community Schools v. Seattle School District No. 1, 229 EDUC. L. REP. 1, 14 (2008); Daniel P. Tokaji, Desegregation, Discrimination and Democracy: Parents Involved's Disregard for Process, 69 OHIO ST. L.J. 847, 861-62 (2008).

170. See San Antonio Indep. Sch. Dist. v. Rodriguez, 411 U.S. 1, 58 (1973); Jesse H. Choper, The Supreme Court and the Political Branches, 122 U. PA. L. REV. 810, 811 (1974) (noting that the Supreme Court and federal judges "appear to be wholly without political responsibility").

171. See Rodriguez, 411 U.S. at 56-58.

172. For arguments that the Supreme Court reached the wrong decision in Rodriguez, see Chemerinsky, supra note 18, at 121 ("The Court had the opportunity to remedy this inequality in education in [Rodriguez] ... [b]ut the court profoundly failed."); Ian Millhiser, What Happens to a Dream Deferred?: Cleansing the Taint of San Antonio Independent School District v. Rodriguez, 55 DUKE L.J. 405, 418 (2005). For scholars who have argued that the school desegregation decisions were wrongly decided, see Millhisen, supra, at 421-22. at 421-22; Bradley W. Joondeph, Killing Brown Softly: The Subtle Undermining of Effective Desegregation in Freeman v. Pitts, 46 STAN. L. REV. 147, 157 (1993); J. John Harris et al., The Curious Case of Missouri v. Jenkins: 
quite compelling. Given the fact that the Court has shown no signs of reversing its decisions in these areas, I believe that a viable alternative to demanding that the Court restructure education federalism lies in inviting the nation to reexamine its understanding of education federalism and insisting on an understanding that supports and even demands equal educational opportunity. I propose such an understanding of education federalism in a future work. ${ }^{173}$

The Court in Rodriguez intentionally deferred the questions raised by disparities in school finance systems to the states 174 but simultaneously acknowledged the need for reform. The Court called for reform of school finance systems in stating:

The need is apparent for reform in tax systems which may well have relied too long and too heavily on the local property tax. And certainly innovative thinking as to public education, its methods, and its funding is necessary to assure both a higher level of quality and greater uniformity of opportunity. ${ }^{175}$

The Court expressly noted the need for innovation to ensure that public education and its funding schemes provide improved quality and greater equality of educational opportunity. Therefore, Rodriguez leaves those seeking equal educational opportunity through school finance systems to the patchwork of state remedies to address these disparities. The next Subpart reveals that in some states these remedies have helped to reduce disparities in educational opportunity, but they have proved inadequate at systematically ensuring equal educational opportunity throughout the nation.

\section{B. The Limitations of State School Finance Litigation and Reform}

In rejecting the plaintiffs' challenges to school finance disparities, the Supreme Court in Rodriguez opined that state and local governments should be the entities to undertake revisions to school finance systems that promote equality of educational opportunity. 176 Since Rodriguez, most states have reformed their school funding system in response to litigation or the threat of litigation or at the initiation of the legislature.177 However, research reveals that, in spite of these efforts and some reduction in disparities in educational opportunity in some states, school finance

The End of the Road for Court-Ordered Desegregation?, 66 J. NEGRo EDUC. 43, 44 (1997).

173. See Robinson, supra note 20.

174. See Rodriguez, 411 U.S. at 58-59.

175. Id. at 58 .

176. See id.

177. See Black, supra note 10, at 1360-65; Sutton, supra note 161, at 1971. 
systems continue to result in significant and inequitable disparities in educational opportunity. ${ }^{178}$

Litigation reform efforts after Rodriguez have sought equity in school finance under state equal protection or education clauses, adequacy under state education clauses, or some combination thereof. ${ }^{179}$ Equity claims oftentimes request reforms to school finance systems that enable students to receive equal per-pupil funding or the guaranteed opportunity to provide equal funding. ${ }^{180}$ Adequacy claims seek sufficient funding to ensure that each child obtains an education that offers a specified level of knowledge or skills. ${ }^{181}$ In spite of the different labels attached to each type of claim, both claims typically seek greater equity in school funding as their ultimate objective. ${ }^{182}$

When pursuing school finance litigation, many plaintiffs have found the state courthouse doors closed to them by courts who viewed the determination of school finance systems to be the sole discretion of state legislatures. For instance, the Florida Supreme Court rejected a school finance case because it would have required the judiciary to invade the duties of the legislature. ${ }^{183}$ The Illinois and Rhode Island Supreme Courts turned away school finance plaintiffs for similar reasons. ${ }^{184}$ Research indicates that when states prevail in school finance litigation they oftentimes reduce state funding for education and thus leave locals to offset these reductions. ${ }^{185}$

Generally, plaintiffs who primarily sought adequacy claims have proven more successful than those bringing equity-focused claims, although each type of claim has enjoyed success in some states. ${ }^{186}$ More than half of the highest state courts have upheld

178. See The EqUity \& EXCELlenCE CoMm'N, supra note 9, at 17, 19; BRUCE D. BAKER ET AL., EDUC. LAW CTR., Is SCHOOL FUNDING FAIR? A NATIONAL REPORT CARD 26-27 (2d ed. 2012); Black, supra note 10, at 1370-71.

179. See RYAN, supra note 7, at 149 (challenging the typical scholarly characterization of school finance as proceeding in three waves); Black, supra note 10, at 1360-64 (describing three waves of school finance litigation).

180. See RYAN, supra note 7, at 149; see, e.g., Brigham v. State, 692 A.2d 384, 390 (Vt. 1997).

181. See RYAN, supra note 7 , at 149; see, e.g., Rose v. Council for Better Educ., Inc., 790 S.W.2d 186, 212 (Ky. 1989).

182. See RYAN, supra note 7 , at 150-51.

183. Coal. for Adequacy \& Fairness in Sch. Funding v. Chiles, 680 So. 2d 400, 408 (Fla. 1996).

184. See Comm. for Educ. Rights v. Edgar, 672 N.E.2d 1178, 1189 (Ill. 1996); City of Pawtucket v. Sundlun, 662 A.2d 40, 58 (R.I. 1995); see also RYAN, supra note 7 , at 147-48 (noting that some scholars applaud such decisions).

185. Christopher Berry, The Impact of School Finance Judgments on State Fiscal Policy, in School Money Trials: The Legal PuRsuit of Educational ADEQUACY 213, 233 (Martin R. West \& Paul E. Peterson eds., 2007).

186. See Black, supra note 10, 1362-65. 
plaintiffs' claims challenging school finance systems. ${ }^{187}$ For instance, the California Supreme Court struck down its school finance system first under the Federal Equal Protection Clause ${ }^{188}$ and, after Rodriguez, under the state equal protection clause, 189 noting that the local control of school funding that the state sought to promote represented "a cruel illusion for the poor school districts."190 The New Jersey Supreme Court held that inequities in its funding system violated the state education clause that guaranteed a "thorough and efficient" education. ${ }^{191}$ The Kentucky Supreme Court's ruling for the plaintiffs identified the knowledge and skills that students must possess upon leaving the school system and required the legislature to establish a system that accomplished that result. ${ }^{192}$ The New Hampshire Supreme Court defined an adequate education based upon students' roles in society. ${ }^{193}$

In response to successful litigation-or sometimes merely the threat of litigation-some states have reformed their school finance systems, including reforms in numerous states that provide additional aid to low-income students, students with special needs, and English language learners. ${ }^{194}$ For instance, New Jersey stands out as a state in which litigation and political mobilization have led to some of the most progressive reforms to its education system. In response to more than a dozen court decisions insisting that the legislature make changes, the New Jersey legislature redistributed large amounts of state aid to poor urban school systems, including approximately $\$ 3.5$ to $\$ 4$ billion in basic education aid that these districts otherwise would not have received. ${ }^{195}$ The Kentucky school finance litigation, along with a concurrent political strategy, led to an overhaul of the Kentucky education system, an increase in revenue for education from both state and local sources, and a

187. See id. at 1397.

188. Serrano v. Priest (Serrano I), 487 P.2d 1241,1244 (Cal. 1971).

189. Serrano v. Priest (Serrano II), 557 P.2d 929, 957-58 (Cal. 1976).

190. Serrano $I, 487$ P.2d at 1260.

191. Robinson v. Cahill, 303 A.2d 273, 295 (N.J. 1973).

192. Rose v. Council for Better Educ., Inc., 790 S.W.2d 186, 212-13 (Ky. 1989).

193. Claremont Sch. Dist. v. Governor, 635 A.2d 1375, 1381 (N.H. 1993).

194. See DAVId HuRst et AL., NAT'L CTR. FOR Educ. STATISTICS, Overview AND INVENTORY OF STATE EDUCATION REFORMS: 1990 To 2000, at 40 (2003), available at http://nces.ed.gov/pubs2003/2003020.pdf; Sean P. Corcoran \& William N. Evans, Equity, Adequacy and the Evolving State Role in Education Finance, in HandBook of Research in EduCation Finance and Policy 332, 334 (Helen F. Ladd \& Edward B. Fiske eds., 2008); Robinson, supra note 19, at 1670; Deborah A. Verstegen \& Teresa S. Jordan, A Fifty-State Survey of School Finance Policies and Programs: An Overview, 34 J. Educ. FIN. 213, 224 (2009).

195. See Michael Paris, Framing EQUal OpPortunity: LaW and THE Politics OF SCHOOL FTNANCE REFORM 147 (2010); RYAN, supra note 7, at 172. 
substantial reduction of the spending disparity between poor and rich districts. 196

Overall, most research indicates that school finance litigation has resulted in additional funding for education, particularly for poor districts, and has reduced inequities in funding schools. ${ }^{197}$ In addition, a study of school finance inequality from 1972 to 2002 found that decreases in inequality in school finance have followed periods of court activity while inequality rose or remained steady during periods of relative inactivity. ${ }^{198}$ Although most, but not all, studies generally agree that litigation has had a positive impact on education finance by raising educational spending and reducing interdistrict spending disparities, ${ }^{199}$ the studies disagree over the impact and influence of this litigation. For instance, one study found a nineteen to thirty-four percent reduction in intrastate spending disparities, ${ }^{200}$ while another more recent study found it to be sixteen percent. ${ }^{201}$ The later study also found that litigation has reduced inequities in spending, but that the net effect has often been quite limited because state spending increases are often offset by decreases at the local level. ${ }^{202}$ One promising trend is that states have begun to provide additional funding for students with additional needs, such as low-income students and special education students. $^{203}$ Although the size of the reduction in spending

196. See PARIS, supra note 195 , at 7-9.

197. See HURST ET AL., supra note 194 , at 47 ; Michael A. Rebell, Courts and Kids: Pursuing Educational Equity Through the STate CourTs 30-31 (2009) ("Virtually all of these studies have concluded that the litigations have resulted in a narrowing of interdistrict expenditure disparities and an increase in educational spending."); KIM REUBEN \& SHEILA MuRRAy, RACIAL DisParities in EduCation Finance: Going Beyond Equal Revenues 4-5 (2008), available at http://www.taxpolicycenter.org/UploadedPDF/411785_equal_revenues.pdf;

David Card \& A. Abigail Payne, School Finance Reform, the Distribution of School Spending, and the Distribution of Student Test Scores, 83 J. PUB. ECON. 49, 67 (2002).

198. See REUBEN \& MURRAY, supra note 197, at 4.

199. REBELL, supra note 197, at 31. But see Berry, supra note 185, at 214 ("In contrast to much of the rhetoric about the revolutionary impact of school finance judgments, I find that they have had relatively small or no effects on most school finance outcomes. On a variety of fiscal measures, ranging from total spending to spending inequality, I find substantively small or statistically insignificant effects of school finance judgments. The most important effect, according to this analysis, has been to accelerate the centralization of school funding to the state level.").

200. Sheila E. Murray et al., Education-Finance Reform and the Distribution of Education Resources, 88 AM. ECON. REV. 789, 806 (1998).

201. Berry, supra note 185 , at 233.

202. Id. at 223.

203. See Verstegen \& Jordan, supra note 194; Martin R. West \& Paul E. Peterson, The Adequacy Lawsuit: A Critical Appraisal, in ScHool MoNEY TRIals: The Legal PURSUIT of EdUCATIONAL ADEQUACY, supra note 185 , at 1,9 10. 
disparities remains unclear, some school finance systems undoubtedly have become more equitable than they were when Rodriguez was decided.

Nevertheless, scholars also have noted that these reforms should not be overstated. ${ }^{204}$ The legislative response to school finance litigation in most states has been described as "fairly tepid," and minority school districts were less likely to prevail and faced extremely hostile legislatures when they did prevail.205 Despite several decades of school finance reform, many school finance systems have remained quite resistant to lasting and comprehensive reform. ${ }^{206}$ One persistent source of disparities in financing education remains the property $\operatorname{tax},{ }^{207}$ an approach that the Court in Rodriguez suggested may have been used for too long. ${ }^{208} \mathrm{~A}$ recent analysis of the current reliance on property taxes reveals that forty states use a foundation program, and five use a combination approach that typically includes a foundation component.209 The foundation approach combines a contribution from local governments that is typically raised through property taxes as well as state funding that seeks to make up the difference between the revenue raised by wealthy and poorer localities. ${ }^{210}$ However, this approach permits inequalities in funding to remain because "[u]sually localities can 'go beyond' the state guaranteed amount with additional property taxes that are unmatched by the state."211 Research indicates that between the 1998-99 school year and the 2008-09 school year, local property taxes consistently accounted for approximately thirty-five percent of funding for schools. ${ }^{212}$

A 2013 report from President Obama's Commission on Equity and Excellence ("the Commission") provides some of the most recent research on the nature and extent of inequitable school finance

204. See Benjamin Michael Superfine, The Courts and Standards-Based EDUCATION REFORM 123 (2008).

205. RYAN, supra note 7, at 171-72.

206. See Douglas S. Reed, On Equal Terms: The Constitutional Politics OF EDUCATIONAL OPPORTUNITY 16 (2001) ("[T]hese reductions in the level of inequality have not substantially altered the institutional contexts of educational finance."); RYAN, supra note 7, at 153.

207. See RYAN, supra note 7, at 153 ("[S]chool funding systems in just about every state continue to be unequal and strongly influenced by differing levels of property wealth.").

208. See San Antonio Indep. Sch. Dist. v. Rodriguez, 411 U.S. 1, 58 (1973).

209. Verstegen \& Jordan, supra note 194, at $215 \&$ tbl.1.

210. Id. at 215 .

211. Id.

212. Susan Aud et al., Nat'l Ctr. for Educ. Statistics, The Condition of EDUCATION 2012, at 192 tbl.A-19-1 (2012), available at http://nces.ed.gov /programs/coe/pdf/coe_sft.pdf. This research also reveals that states vary in their reliance on property taxes from lows of zero percent or close to zero percent in Hawaii and Vermont to highs of fifty-five percent in New Hampshire and Connecticut. Id. at 54. 
disparities within the United States that remain even after numerous state efforts to reform school finance systems. President Obama created the Commission to study disparities in educational opportunity and emphasized the need to focus on school finance systems and to recommend how the federal government could assist in remedying these disparities. ${ }^{213}$ The Commission brought together many of the nation's leading experts on education finance and reform as well as business leaders and many of the nonprofit organizations that consistently work on issues of equity in education. ${ }^{214}$ In a February 2013 report, the Commission found that deeply entrenched inequities remain in the nation's school finance systems despite a finding by a federal commission in 1972 that the inequities and inadequacies in the nation's school finance systems were caused by outdated school finance formulas that depended too heavily on property taxes. ${ }^{215}$ The report acknowledged that many states have decreased their reliance on property taxes and have used the increased reliance on state funding to increase equity. ${ }^{216}$ However, the report noted that despite four decades of reforms by federal, state, and local governments these reforms have failed to create equitable and adequate school finance systems. ${ }^{217}$ Indeed, the Commission summarized its finding that these reforms have fallen short by stating that:

These initiatives have not addressed the fundamental sources of inequities and so have not generated the educational gains desired. Despite these efforts and proclamations, large achievement gaps remain, and local finance and governance systems continue to allow for, and in many ways encourage, inequitable and inadequate funding systems and inefficient and ineffective resource utilization. ${ }^{218}$

The report further condemned school finance systems, with only limited exceptions, for failing to link school finance systems to the cost of ensuring that all students achieve high standards. ${ }^{219}$ The report also confirmed that the nation's education system continues to confine poor and minority communities to the poorest-performing teachers, poorly maintained facilities, and inferior academic

213. See U.S. DeP'T of Educ., Charter of THE EquTtY and Excellence Commission 1 (2011), available at http://www2.ed.gov/about/bdscomm/list/eec /documents.html.

214. U.S. Secretary of Education Appoints Members of Equity and Excellence Commission, U.S. DEP'T EDUC. (Feb. 17, 2011), http://www.ed.gov/news/press -releases/us-secretary-education-appoints-members-equity-and-excellence -commission.

215. ThE EQUiTY \& EXCELlENCE COMM'N, supra note 9, at 17.

216. See id.

217. See id. at 19.

218. See id. (emphasis added).

219. See id. at 17. 
opportunities and expectations. ${ }^{220}$ In light of this unequivocal condemnation of the nation's school finance systems, the report recommended a variety of reforms by the states and the federal government that would restructure school finance systems to provide for an efficient distribution of adequate resources that are allocated based upon students' needs and that would enable all students to achieve high standards. 221

Other research also confirms that many school finance systems within the United States fail to provide an adequate and equitable distribution of education funding. For instance, a 2012 report entitled Is School Funding Fair? A National Report Card assessed the school finance systems of all fifty states against four fairness measures: (1) funding level-the level of state and local funding for school districts compared to that of other states; (2) funding distribution-whether a state provides additional funding or reduces funding to schools based on the concentration of student poverty; (3) effort-which compares the difference between state spending on education relative to the fiscal capacity of the state based on its per capita gross domestic product; and (4) coverage-the percentage of students in the state who attend public schools. ${ }^{222}$ The resulting analysis provides a multifaceted and comprehensive assessment of the school finance systems throughout the nation that stands in contrast to many studies that simply use one measure of inequality.

Several key findings highlight existing inequities in school finance systems. The report notes that states have the most control over two factors-funding distribution and effort.223 In particular, funding distribution provides the greatest insight into whether states attempt to address the additional educational needs of lowincome students. ${ }^{224}$ On this measure, "[o]nly 17 states have progressive funding systems, providing greater funding to highpoverty districts than to low-poverty districts," which represents an increase from the fourteen states that were progressive in the 2010 report. ${ }^{225}$ Sixteen states have regressive systems that give less money to high-poverty districts, and fifteen states provide the same

220. See id. at 14.

221. See id. at 17-20.

222. BAKER ET AL., supra note 178, at 6-7. The authors are scholars of school finance, and David Sciarra, one of the nation's leading school finance attorneys, litigated the New Jersey school finance litigation.

223. Id. at 10 .

224. See id. at $13,14 \&$ tbl.3.

225. Id. at 13. These states are California, Connecticut, Delaware, Georgia, Indiana, Kentucky, Massachusetts, Minnesota, Montana, Nebraska, New Jersey, New Mexico, Ohio, South Dakota, Tennessee, Utah, and Wyoming. Id. at 15 fig. 3 . Hawaii is omitted from the analysis because it is a single district and Alaska is omitted because the state's parse population and geography created inconsistent measures of funding distribution under the model used in the study. See id. at 13. 
level of funding to high- and low-poverty districts. ${ }^{226}$ This reveals that only slightly more than one-third of the school finance systems are sending additional revenue to address the well-documented greater needs of low-income students. ${ }^{227}$ The report also notes that between 2007 and 2009, thirty-four states increased their effort, but that states varied widely in the effort made to fairly fund schools. ${ }^{228}$ The report further highlights the importance of both sufficient and progressive funding systems as an indispensable foundation for raising student achievement and closing the achievement gaps. ${ }^{229}$

Ultimately, this research reveals that, although important reforms have undoubtedly occurred and have improved educational opportunities for many children, these reforms have not been consistently sufficient and comprehensive enough to end longstanding, inequitable disparities in educational opportunity throughout the nation. Numerous scholars have noted the insufficiency of these reforms. ${ }^{230}$ For instance, after surveying the research on the impact of school finance litigation, education law scholar Derek Black concluded that "[t]he most accurate general characterization of adequacy and equity litigation ... is that it has produced a net benefit, but significant and troublesome inequalities still persist."231 Similarly, education law and policy scholar Benjamin Michael Superfine has characterized the impact of school finance litigation as "somewhat limited" due to the longstanding challenges facing education litigation generally, including vague legal standards, empirical questions about central issues, and political hostility to reform. ${ }^{232}$ Further, he notes that equalization

226. Id. at 13. The regressive states are Alabama, Colorado, Florida, Idaho, Illinois, Maine, Michigan, Missouri, Nevada, New Hampshire, New York, North Carolina, North Dakota, Pennsylvania, Texas, and Virginia. Id. at 15 fig.3. The states that provide essentially level funding between low- and high-poverty districts are Arizona, Arkansas, Iowa, Kansas, Louisiana, Maryland, Mississippi, Oklahoma, Oregon, Rhode Island, South Carolina, Vermont, Washington, West Virginia, and Wisconsin. Id.

227. See id. at 13.

228. Id. at 23 .

229. Id. at 28 .

230. See, e.g., William J. Glenn, School Finance Adequacy Litigation and Student Achievement: A Longitudinal Analysis, 34 J. EDuC. Fin. 247, 262-63 (2009) (finding that adequacy litigation has a small positive effect on the achievement of students from very low socioeconomic backgrounds and that such reform should be included in overall comprehensive school reform); Christopher Roellke et al., School Finance Litigation: The Promises and Limitations of the Third Wave, 79 PEABODY J. EDUC. 104, 105 (2004) ("Despite intensified school finance litigation and legislation over the past several decades, school systems in the United States continue their struggle to operate equitably and adequately. The evidence is clear that these goals of equity and adequacy have been particularly elusive for schools attended primarily by lowincome and minority children.").

231. Black, supra note 10, at 1371 (footnotes omitted).

232. SUPERFINE, supra note 204. 
oftentimes did not require increased educational spending and that test scores ultimately have not improved even when spending was increased. ${ }^{233}$ Indeed, the resistance of most school finance systems to comprehensive reform prompted leading education law scholar James Ryan to comment recently that even when state school finance litigation has succeeded, the results have been "modest" and "not a single suit has done much to alter the basic structure of school finance schemes." 234 Therefore, important reforms of state school finance systems have occurred that have addressed some of the disparities in educational opportunity, but these reforms have not ended the funding inequities that result in substandard schools for many disadvantaged schoolchildren. 235

Even though the Court in Rodriguez called for reform of the nation's school finance systems to advance equal educational opportunity, ${ }^{236}$ the local control of education that was supposed to encourage experimentation simply has failed to foster comprehensive and effective state efforts that eliminate inequitable disparities in educational opportunity. Although some contend that such experimentation and reform suggests the Court in Rodriguez correctly left this issue to the states, ${ }^{237}$ the steadfast persistence in disparities in educational opportunity that harm disadvantaged students indicates the Court's trust in states to end these disparities may have been misplaced. Therefore, closing the federal courthouse door to school finance litigation has left disadvantaged schoolchildren without a means to obtain comprehensive and lasting reform of school finance systems that continue to tolerate significant and inequitable disparities in educational opportunity. Given the limited impact of state school finance litigation and reform, Rodriguez remains essential to understanding how education federalism has served as one of the hindrances to the nation's efforts to achieve equal educational opportunity.

The next Part shows how education federalism limited the potential effectiveness of NCLB.

\section{EDUCATION FEDERALISM AND THE No CHILD LEFT BEHIND ACT OF 2001}

The No Child Left Behind Act of 2001 represents the most farreaching federal legislative effort to advance educational equity and

233. Id. at 123-24.

234. RYAN, supra note 7, at 153.

235. See id. at 153-54, 178; Black, supra note 156, at 1357, 1371.

236. See San Antonio Indep. Sch. Dist. v. Rodriguez, 411 U.S. 1, 50-51 (1973).

237. See, e.g., Sutton, supra note 161. 
excellence in the nation's history. ${ }^{238}$ The founding legislation for NCLB, the Elementary and Secondary Education Act of 1965,239 focused on providing additional resources to disadvantaged students to attempt to bridge the opportunity gap between these students and their more affluent peers. ${ }^{240}$ Subsequent reauthorizations built upon this focus on low-income students while also expanding federal assistance to particular populations of students, such as English language learners. ${ }^{241}$ This federal legislation eventually embraced the standards and accountability movement by requiring states to adopt the same rigorous academic standards for all students through the Improving America's Schools Act of $1994 .{ }^{242}$ NCLB is a bipartisan congressional attempt to begin to close both the achievement gap and the opportunity gap. ${ }^{243}$ It substantially expanded and restructured the federal role in elementary and secondary education and, in doing so, ultimately shaped a new education federalism. ${ }^{244}$

However, even as NCLB was reshaping education federalism, education federalism handicapped NCLB's ability to effectively address the achievement and opportunity gaps. This Part analyzes how education federalism hindered two key NCLB provisions: the requirement that all states adopt challenging academic standards and the requirement that all classrooms have a highly qualified teacher. This analysis reveals that even the most far-reaching federal effort to promote equity and excellence in education could not escape the policymaking constraints of education federalism.

238. No Child Left Behind Act of 2001, Pub. L. No. 107-110, 115 Stat. 1425 (codified as amended in scattered sections of 20 U.S.C.); see MCGUINN, supra note 3 , at 1 .

239. Pub. L. No. 89-10, 79 Stat. 27.

240. See MCGUINN, supra note 3, at 1, 31 .

241. See Manna, Collision Course, supra note 3 , at 5 .

242. Pub. L. No. 103-382, §§ 1111-1112, 108 Stat. 3518, 3523-32; see Manna, Collision Course, supra note 3 , at 6.

243. See No Child Left Behind Act of 2001, Pub. L. No. 107-110, 115 Stat. 1425 (noting that NCLB seeks " $[t]$ o close the achievement gap with accountability, flexibility, and choice, so that no child is left behind"); 20 U.S.C. $\S 6301$ (2006) (noting that NCLB seeks "to ensure that all children have a fair, equal, and significant opportunity to obtain a high-quality education and reach, at a minimum, proficiency on challenging state academic achievement standards and state academic assessments"); MANNA, ColLISION CouRsE, supra note 3, at 22-23; MCGuINN, supra note 3, at 175-76.

244. See McGuINN, supra note 3, at 1, 195. But see Lorraine M. McDonnell, No Child Left Behind and the Federal Role in Education: Evolution or Revolution?, 80 PEABODY J. EDUC. 19, 19-21 (2005) (arguing that NCLB represents the continuing evolution of past federal education policy rather than a revolution in the federal role in education). 


\section{A. How Education Federalism Influenced the Requirements for Challenging Academic Standards in NCLB}

To understand how education federalism limited NCLB's potential effectiveness, it is important to understand the key components of NCLB. NCLB requires all states to adopt "challenging" academic standards at a minimum in math, reading, and science that are applied to all students. ${ }^{245}$ Students must be tested on their knowledge of these standards annually in grades three through eight and once in grades ten through twelve in reading and math beginning in the 2005-06 school year. ${ }^{246}$ Beginning in the 2007-08 school year, science testing must be conducted once in each of three grade spans: grades three to five, grades six to nine, and grades ten to twelve. ${ }^{247}$ States also must define cut scores that determine when students are proficient on state tests, and those scores must be separately reported for student subgroups, including separate scores for racial and ethnic minority students and low-income students. ${ }^{248}$ NCLB requires all schools and districts to publish annual report cards detailing graduation rates, school performance, and whether students and subgroups of students are making adequate yearly progress ("AYP") toward the goal of proficiency for all students by 2014.249 NCLB also imposes accountability requirements on schools and districts that receive funding under Title I. ${ }^{250}$ These requirements generally impose increasingly interventionist corrective action each year that a school or a subgroup within a school did not achieve proficiency on state tests. ${ }^{251}$

Despite these reformist requirements, the current understanding of education federalism has handcuffed the most progressive elements of NCLB. NCLB's requirement that all students become proficient at "challenging" academic standards lies at the heart of its effort to close the achievement gap. However, rather than propose rigorous common standards for all students, the existing structure of education federalism led Congress to allow each

245. 20 U.S.C. $\S 6311(\mathrm{~b})(1)(\mathrm{A})-(\mathrm{C})$.

246. $I d . \S 6311(\mathrm{~b})(3)(\mathrm{A})-(\mathrm{C})$.

247. Id. $\S 6311(\mathrm{~b})(3)(\mathrm{C})(\mathrm{v})(\mathrm{II})$.

248. The subgroups for reporting NCLB scores are gender, major racial and ethnic minority groups, economically disadvantaged students, English language learners, and disabled students. See id. $\S 6311(\mathrm{~b})(3)(\mathrm{A})$, (b)(3)(C)(xiii).

249. See id. $\S 6311(\mathrm{~b})(2)(\mathrm{F}),(\mathrm{c})(1)$, (h); see also MANNA, Collision Course, supra note 3 , at 24 . If a school or a particular subgroup is not proficient, it could show it made AYP if it satisfied a "safe harbor" requirement of demonstrating substantial improvement for the school or subgroup. See id. at 25.

250. See 20 U.S.C. $\S 6316(\mathrm{~b})(1)(\mathrm{A}),(5),(7),(8)$.

251. See id. 
state to set its own academic standards. ${ }^{252}$ Indeed, as professor of government Paul Manna has noted, "Long-standing political concerns and views of American federalism, such as the tradition of state and local control of curriculum and teaching, kept some options such as federally developed standards and tests off the negotiating table from the start."253 Furthermore, the statute ensures that the Department of Education will not exert influence over the content of the standards by specifically stating that "a State shall not be required to submit such standards to the Secretary [of Education]."254 Allowing states to set academic standards provides states with an opportunity to establish rigorous academic standards that would prepare students for success in postsecondary education, employment, and their communities. ${ }^{255}$

Unfortunately for the nation's schoolchildren, and ultimately the nation, the states did not embrace this opportunity. Instead, many states used the flexibility within NCLB as an opportunity to lower standards to those that were easily attainable to avoid the penalties and the reforms that would be required if students did not reach demanding standards. ${ }^{256}$ The weak standards eviscerated the proficiency requirement and instead made proficiency mean very little in many states. ${ }^{257}$ As a result, student proficiency on state tests did not ensure that students were well prepared for the workforce or college. 258

Even though education federalism limited Congress's ability to adopt a national standard, Congress tried to prevent states from adopting low standards by requiring states to test a sample of students on the National Assessment of Educational Progress ("NAEP"), a standardized achievement test on reading and math for fourth and eighth graders.259 However, this check proved

252. See Gary Wasserman, Politics in Action: Cases from the Frontlines OF AMERICAN GOVERNMENT 23 (Reid Hester ed., 2011).

253. MANNA, Collision Course, supra note 3 , at 41 ; see also Ryan, supra note 162, at 53-54 (arguing that NCLB's exclusion of provisions conditioning federal funds on such things as national standards or a national curriculum demonstrates that Congress chose to limit its reach to recognize state and local authority over education).

254. 20 U.S.C. $\$ 6311(\mathrm{~b})(1)(\mathrm{A})$.

255. See MANNA, Collision Course, supra note 3 , at 152.

256. See id. at 47,153 , supra note 3 , at 47,153 ; WASSERMAN, supra note 252 ; Paul E. Peterson \& Carlos Xabel Lastra-Anadón, State Standards Rise in Reading, Fall in Math, EDUC. NEXT, Fall 2010, at 13-14, available at http://educationnext.org/files/ednext_20104_12.pdf.

257. See MANNA, Collision Course, supra note 3, at 153; Mike Johnston, From Regulation to Results: Shifting American Education from Inputs to Outcomes, 30 YALE L. \& PoL'y REv. 195, 197 (2011).

258. See WASSERMAN, supra note 253.

259. 20 U.S.C. $\S 6311(c)(2)$; Robinson, supra note 19, at 1680; Peterson \& Lastra-Anadón, supra note 256, at 13. 
insufficient to the task. ${ }^{260}$ Most states have adopted significantly weaker standards than the NAEP standards. ${ }^{261}$ Indeed, one study found that "[e]very state, for both reading and math (with the exception of Massachusetts for math), deems more students 'proficient' on its own assessments than NAEP does."262 The NAEP data also reveal that less than one-third of the students in the United States are proficient in reading and that a similar percentage of students are proficient in math. ${ }^{263}$

Although states continue to adjust their standards and many have committed in the last few years to adopt common standards in response to federal money offered under President Obama's Race to the Top Initiative, ${ }^{264}$ this analysis reveals that the congressional genuflect to education federalism eviscerated the heart of NCLB by preventing Congress from establishing a meaningful floor for state education standards. Without any limits on the rigor of state standards, many states chose to adopt weak academic standards. The next Subpart reveals that education federalism also limited the effectiveness of NCLB's requirement that every classroom must have a highly qualified teacher in districts that receive Title I funds.

260. Peterson \& Lastra-Anadón, supra note 256; Robinson, supra note 19, at 1680.

261. See Peterson \& Lastra-Anadón, supra note 256.

262. See id. at 14.

263. See id. at 16.

264. See id. at 14-16. The Obama Administration's Race to the Top program provided federal incentives for states to adopt state-developed common standards as one of the criterion for obtaining Race to the Top funds. See Race to the Top Fund: Notice Inviting Applications for New Awards for Fiscal Year (FY) 2010, 74 Fed. Reg. 59,836, 59,836 (Nov. 18, 2009). Nevertheless, Alaska, Minnesota, Nebraska, Texas, and Virginia refused to adopt these standards despite the large sums of federal funds that potentially could have been obtained through this competitive process. In the States, COMMON CORE ST. STANDARDS INITIATIVE (Feb. 15, 2013, 3:25 PM), http://www.corestandards.org /in-the-states. In addition, the rigor of these standards and the future implementation of common standards remain uncertain because substantial criticisms of these standards have been raised, including concerns about the potential for adopting weak standards and a lack of detail in the standards that could render them ineffective at guiding curriculum. See Sean Cavanagh, Resurgent Debate, Familiar Themes: Common-Standards Push Bares Unsettled Issue, EDUc. WK., Jan. 14, 2010, at 5, 11. Also, even if the standards help to increase the rigor of state standards, most states did not obtain Race to the Top funds to assist in the development and implementation of these standards, so it remains unclear how committed they will remain to implementing these standards in a time of scarce economic resources for schools. In addition, it also is unclear what "adoption" of these common standards will mean for each state as the states are free to adopt, incorporate, or modify these standards as they see fit. See id. at 5. 


\section{B. Education Federalism and the Highly Qualified Teacher Requirement for $N C L B$}

Research establishes that urban schools with high concentrations of low-income and minority students typically employ less qualified, experienced, and effective teachers. ${ }^{265}$ To address this disparity, NCLB sought to close this aspect of the opportunity gap by requiring a highly qualified teacher in every classroom for core academic subjects in districts that accept Title I funds. ${ }^{266}$ NCLB defines a highly qualified teacher as one who holds a bachelor's degree, possesses competence in the subject that she teaches, and, obtains full state certification or passes a state licensing exam and holds a license to teach. 267 NCLB required states to ensure that teachers in core subjects were highly qualified by the 2005-06 school year. ${ }^{268}$ To show competence to teach, a new teaching applicant for an elementary teaching position must pass a state exam in math, reading, and writing. ${ }^{269} \mathrm{~A}$ new teaching applicant for a middle school or high school position could show competence in one of three ways: pass a state exam in the subjects he or she will teach; possess a postsecondary major or the equivalent coursework or a graduate degree in the teaching subject; or, obtain credentialing demonstrating their knowledge. 270 Veteran teachers could show competency in the same way, but NCLB also gave veteran teachers the option to show competence by demonstrating that they met a state standard of evaluation. ${ }^{271}$ The statute does not provide a federal minimum for demonstrating mastery in a subject. 272

Congressional concerns regarding education federalism limited the effectiveness of these provisions. To safeguard state control of teacher licensure standards, Congress provided broad flexibility to states in defining a highly qualified teacher by allowing state licensure or certification and successful completion of a state test in the relevant subject area to establish the definition of highly

265. See RYAN, supra note 7, at 173; see also Molly S. McUsic, The Future of Brown v. Board of Education: Economic Integration of the Public Schools, 117 HARV. L. REV. 1334, 1351-52 (2004); Motoko Akiba et al., Teacher Quality, Opportunity Gap, and National Achievement in 46 Countries, 36 EDUC. RESEARCHER 369, 369-70 (2007); Linda Darling-Hammond \& Barnett Berry, Recruiting Teachers for the 21st Century: The Foundation for Educational Equity, 68 J. NEGRo EDUC. 254, 256 (1999).

266. 20 U.S.C. $\$ \S 6319(a), 6311(\mathrm{c})(1)$, (h) (2006). Core academic subjects are math, science, reading or language arts, English, civics and government, geography, history, the arts, economics, and foreign languages. Id. $\S 7801$ (11).

267. Id. $\S 7801(23)(\mathrm{A})-(\mathrm{C})$.

268. Id. $\$ 6319(\mathrm{a})(2)$.

269. Id. $\S 7801(23)(\mathrm{B})(\mathrm{i})(\mathrm{II})$.

270. Id. $\$ 7801(23)(\mathrm{B})(\mathrm{ii})$.

271. Id. $\S 7801(23)(\mathrm{C})(\mathrm{i})-(\mathrm{ii})$

272. Kathleen Porter-Magee, Teacher Quality, Controversy, and NCLB, 78 CleARING House 26, 28 (2004). 
qualified. ${ }^{273}$ Like the flexibility for student standards, this flexibility enabled states to lower standards for teachers. ${ }^{274}$ In response to this flexibility, "many states have developed low standards for defining what constitutes" a highly qualified teacher, particularly when they encountered implementation difficulties such as teacher shortages and insufficient data and information to track teacher qualifications. ${ }^{275}$ Indeed, although some contend that most states adopted rigorous standards for new teacher certification, ${ }^{276}$ other scholars allege that states have used this flexibility to ensure that definitions of quality impose "no additional burden on either existing teachers or new entrants" because the definitions simply replicate preexisting certification and licensing standards. ${ }^{277}$ This enabled states to require only minimal competence 278 and to identify the largest number of highly qualified teachers while avoiding significant repercussions for identifying substantial numbers of teachers who do not meet the requirements for being highly qualified. ${ }^{279}$ This research indicates that state efforts to adopt a rigorous definition of a highly qualified teacher represent the exception rather than the rule. 280

Undoubtedly, other federal action also undermined the effectiveness of the highly qualified teacher requirements. 281 For instance, the federal government issued inconsistent guidance and

273. See 20 U.S.C. $\$ 7801$ (23); MANNA, Coldision CourSE, supra note 3, at 30.

274. See MANNA, Collision Course, supra note 3 , at 47.

275. SUPERFINE, supra note 204, at 52.

276. See, e.g., Regina R. Umpstead \& Elizabeth Kirby, Reauthorization Revisited: Framing the Recommendations for the Elementary and Secondary Education Act's Reauthorization in Light of No Child Left Behind's Implementation Challenges, 276 EDUC. L. REP. 1, 13 (2012) ("[M]ost states developed rigorous requirements for new teacher certification ...."). But see Kate Walsh, Through the Looking Glass: How NCLB's Promise Requires Facing Some Hard Truths About Teacher Quality, 78 ClEARING House 22, 24 (2004) ("The standards [for highly qualified teachers] ranged from reasonable attempts to meet the spirit of the law to approaches that can best be described as indifferent and, at times, even disdainful of what the law is trying to do.")

277. Eric A. Hanushek \& Steven G. Rivkin, The Quality and Distribution of Teachers Under the No Child Left Behind Act, 24 J. ECON. PERSP. 133, 135-36 (2010); see also Barnett Berry et al., The Search for Highly Qualified Teachers, 85 PHI Delta KaPPan 684, 686 (2004); Porter-Magee, supra note 272, at 29; Benjamin Michael Superfine, Using the Courts to Influence the Implementation of No Child Left Behind, 28 CARDOzo L. REv. 779, 794 (2006).

278. Michael A. Rebell \& Molly A. Hunter, 'Highly Qualified' Teachers: Pretense or Legal Requirement?, 85 PHI DELTA KAPPAN 690, 692 (2004).

279. Porter-Magee, supra note 272.

280. Rebell \& Hunter, supra note 278 , at 693.

281. State implementation of the highly qualified teacher requirement also contributed to the limited impact of this provision. For instance, states distributed funding for teachers quite broadly to fund recruitment and training for highly qualified teachers rather than channeling these funds to schools that had failed to meet the highly qualified teacher mandates. SUPERFINE, supra note 204 , at 52 (2008). 
did not effectively enforce the requirements. ${ }^{282}$ In addition, the federal government did not provide any support to states to help ensure an adequate pool of qualified teachers.283 However, these additional failures on the part of the federal government only highlight that the statute needed a more rigorous definition of a highly qualified teacher that would have curbed state tendencies to lower standards when difficulties arose or additional federal financial support was not forthcoming.

The flexibility within and the limitations on the highly qualified teacher provision caused by education federalism are particularly important because NCLB does not otherwise attempt to address the substantial disparities in the opportunity to learn state standards. ${ }^{284}$ Instead, NCLB requires all students to be proficient by 2014 even though many low-income and minority students do not receive the educational opportunities and resources that they would need to reach this standard.285 Although the states undoubtedly enjoy the freedom to eliminate these disparities in educational opportunity, Subpart II.B establishes that so far the overwhelming majority of states typically have chosen to tolerate these disparities rather than eliminate them in systematic and sustained ways. 286

NCLB also reflects federalism limits because it does not establish a federal curriculum or a federal assessment system, and it does not indicate how states should determine when a school is failing. ${ }^{287}$ Even though Congress could have enacted such provisions under the Spending Clause, these provisions were omitted to preserve state and local authority over these aspects of education. ${ }^{288}$ However, the omission of some of these requirements also prevented the law from moving the nation closer to challenging academic standards and tests for all children as well as a consistently demanding definition for when a school should be labeled "failing."

In addition, congressional insistence that the states must define standards for academics and for teachers reflects a somewhat dualist understanding of some areas of education law and policy. Even as NCLB restructured and greatly expanded the role of education, the refusal to adopt a floor for state standards indicates that Congress believed that these standards must remain the sole

282. See Manna, Collision CouRse, supra note 3 , at 55-57.

283. See Linda Darling-Hammond, From "Separate but Equal" to "No Child Left Behind": The Collision of New Standards and Old Inequalities, in MANY ChILDREN LEFT BeHIND: How THE No ChILd LEFT BeHIND ACT Is DAMAging OUR ChILdREn AND OUR Schools 3, 29 (Deborah Meier \& George Wood eds., 2004).

284. See REBELL \& WOLFF, supra note 7.

285. See id.

286. See discussion supra Subpart II.B.

287. See Ryan, supra note 162 , at 54 .

288. See id. 
province of the states. Although this decision represents an understandable compromise in a statute that expanded federal authority over education greater than any past reauthorization of the Elementary and Secondary Education Act, it is important to recognize that it is this understanding of the state role in education as the sole determinant of standards that served as one of the principal weaknesses within the statute that undermined its effectiveness.

This research and analysis reveals that education federalism hindered NCLB's goals of reducing the achievement and opportunity gaps. 289 NCLB undoubtedly changed the federal-state balance of power by expanding the federal role in education. However, the congressional attempts to preserve aspects of the existing balance of federal-state authority over education ultimately undermined Congress's ability to adopt more effective provisions that could have assisted NCLB's efforts to close the achievement and opportunity gaps.

\section{CONCLUSION}

Undoubtedly, no one factor can explain the failure of decades of school reform efforts. A variety of additional factors have hindered these reforms, and the above analysis is not attempting to suggest otherwise. Even with this essential caveat, it is important to recognize the consistent ways that education federalism limited several reforms as scholars, educators, and policy-makers attempt to understand why the nation continues to provide substandard educational opportunity to many students. This understanding will provide a crucial foundation for building more effective and comprehensive reforms in the future.

Furthermore, education federalism's past hindrance of efforts to advance equal educational opportunity raises an important question: does education federalism need to be restructured to allow for effective federal efforts to ensure equal access to an excellent education? This question is particularly relevant as scholars, politicians, and advocacy groups are proposing a variety of recommendations for the reauthorization of the Elementary and Secondary Education Act. ${ }^{290}$ In a future work, I consider this timely

289. See MANNA, Collision CoURSE, supra note 3, at 22-23.

290. See Elementary and Secondary Education Amendments Act of 2011, S. 1571, 112th Cong.; Elementary and Secondary Education Reauthorization Act of 2011 , S. 3578, 112th Cong.; THE COMM'N. ON No CHILD LEFT BEHIND, BEYOND NCLB: Fulfilling the Promise to OUR NATION'S ChIldRen 161-69 (2007), available at http://www.aucd.org/docs/Aspen\%20Commission\%20on \%20NCLB.pdf; NAT'L EDUC. ASS'N, NEA's LEGISLATIVE RECOMMENDATIONS FOR REAUTHORIZATION OF THE ELEMENTARY AND SECONDARY EDUCATION ACT 1-21 (2010), available at http://www.nea.org/assets/docs/HE/NEA_Legislative _Specifications_on_ESEA_MAY2010.pdf; NAT'L SCH. BDS. ASS'N, 
question. In the meantime, it is important to acknowledge the systematic ways that education federalism hampered past efforts to ensure equal educational opportunity as the nation considers adopting new efforts to achieve this vital national goal.

RECOMMENDATIONS FOR THE REAUTHORIZATION OF THE ELEMENTARY AND SECONDARY EDUCATION ACT 1-10 (2010), available at http://www.nsba.org /Advocacy/Key-Issues/NCLB; Damon T. Hewitt, Reauthorize, Revise, and Remember: Refocusing the No Child Left Behind Act to Fulfill Brown's Promise, 30 YALE L. \& POL'Y REV. 169, 179-80, 186, 192, 194 (2011) ("[I]n order to be maximally effective in [NCLB's] next attempt to realize the ESEA's goal of equitable options for all children, policy makers must resist calls for a downgraded federal role in public education."); Kamina Aliya Pinder, Federal Demand and Local Choice: Safeguarding the Notion of Federalism in Education Law and Policy, 39 J.L. \& EDUC. 1, 19 (2010) ("The next iteration of the ESEA should minimize the federal role in enforcing state benchmarks...."); Umpstead \& Kirby, supra note 276, at 19-24 (2012) ("In an effort to redirect the prevailing problems in NCLB and to provide recommendations from those that understand schooling best, national education organizations have created position statements regarding ESEA reauthorization that make recommendations about how to best address academic achievement, the instructional program, teacher quality, and other pressing issues."); Sam Dillon, Obama Cails for Major Change in Education Law, N.Y. TTMES, Mar. 13, 2010, at A1 ("Administration officials laid out their blueprint in briefings Friday and Saturday with governors, lawmakers, education organizations and journalists. Officials said they intended to leave the drafting of a bill up to Congress."). 